\title{
Recomendaciones para el diagnóstico y el manejo de la infección por citomegalovirus en la mujer embarazada y el recién nacido
}

\section{Recommendations for the diagnosis and management of cytomegalovirus infection in pregnant women and newborns}

\author{
Giannina Izquierdo1,2,3*, Alejandra Sandoval4,5, Fernando Abarzúa ${ }^{6}$, Macarena Silva ${ }^{1,7}$, Juan P. Torres ${ }^{1,8}$, \\ Masami Yamamoto ${ }^{9}$, Juan G. Rodríguez ${ }^{1,10}$, Marta Aravena ${ }^{11}$, Daniela Fuentes ${ }^{4}$, Alejandra Reyes ${ }^{12}$, Natalia \\ Conca $^{8}$, Fernanda Cofré13, Luis Delpiano ${ }^{7}$, Mariluz Hernandez ${ }^{14}$, Loreto Twele ${ }^{15}$, Yenis Labraña ${ }^{16}$, Marcela \\ Ferrés ${ }^{17}$, Gloria Ribalta ${ }^{18}$, Angela Chuang ${ }^{19}$, Ximena Ortega ${ }^{20}$, Bárbara Oliva ${ }^{5,21}$ y Estebeni Baltra ${ }^{5,22}$
}

Facultad de Medicina, Universidad de Chile, Santiago; ${ }^{2}$ Servicio de Neonatología, Hospital Barros Luco Trudeau, Santiago; ${ }^{3}$ Unidad de Infectología, Hospital de Niños Dr. Exequiel González Cortés, Santiago; ${ }^{4}$ Unidad de Infectología, Hospital Carlos Van Buren, Valparaíso; ${ }^{5}$ Facultad de Medicina, Universidad de Valparaíso; ${ }^{6}$ Servicio de Ginecología y Obstetricia, Hospital Hernán Henriquez Aravena, Temuco y Clínica Alemana de Temuco, Temuco; ${ }^{7}$ Unidad de Infectología, Hospital San Borja Arriarán, Santiago; ${ }^{8}$ Unidad de Infectología, Hospital de Niños Dr. Luis Calvo Mackenna, Santiago; ${ }^{9}$ Servicio de Ginecología y Obstetricia, Clínica Universidad de los Andes, Santiago; ${ }^{10}$ Centro de Referencia Perinatal Oriente, CERPO, Santiago; ${ }^{11}$ Unidad de Infectología, Hospital Gustavo Fricke, Viña del Mar; ${ }^{12}$ Unidad de Infectología, Hospital Félix Bulnes, Santiago; ${ }^{13}$ Unidad de Infectología, Hospital de Niños Roberto del Río, Santiago; ${ }^{14}$ Unidad de Infectología, Hospital Santiago Oriente Luis Tisne B, Santiago; ${ }^{15}$ Unidad de Infectología y Servicio de Neonatología, Hospital Puerto Montt. Puerto Montt; ${ }^{16}$ Unidad de Infectología, Hospital San Juan de Dios, Santiago; ${ }^{17}$ Facultad de Medicina y Hospital Clínico Universidad Católica de Chile, Red Salud UC-Christus, Santiago; ${ }^{18}$ Servicio de Otorrinolaringología, Clínica MEDS, Santiago; ${ }^{19}$ Servicio de Otorrinolaringología, Hospital Barros Luco Trudeau, Santiago; ${ }^{20}$ Servicio de Imágenes, Clínica Las Condes, Santiago; ${ }^{21}$ Servicio de Imágenología, Hospital Carlos Van Buren, Valparaíso; ${ }^{22}$ Departamento de Neurología, Hospital Gustavo Fricke, Viña del Mar. Chile

\section{Resumen}

La Sociedad Chilena de Infectología, a través de su Comité de Infecciones Neonatales, en conjunto con la Sociedad Chilena de Obstetricia y Ginecología, proponen un documento de diagnóstico y manejo de la infección por citomegalovirus (CMV) en la mujer embarazada y el recién nacido. Esta guía aborda el manejo de la infección en el binomio, su enfrentamiento diagnóstico y terapéutico, orientado al equipo de salud que atiende a mujeres embarazadas y recién nacidos con infección por CMV en Chile. Considera la situación epidemiológica global y latinoamericana, con recomendaciones para la evaluación clínica y de laboratorio; establece criterios de diagnóstico, propone enfoques terapéuticos de acuerdo a la situación clínica, analiza las medidas de prevención y establece una propuesta nacional para el seguimiento de esta enfermedad. Se ha puesto especial énfasis en entregar, de forma práctica, y con la mayor evidencia posible, las recomendaciones para el manejo del binomio con infección por CMV.

Palabras clave: Citomegalovirus. Embarazo. Neonato. Infección congénita. Diagnóstico prenatal. SCORTCH.

\section{Abstract}

The Chilean Society of Infectology, through its Neonatal Infections Committee in conjunction with the Chilean Society of Obstetrics and Gynecology, propose a document for the Diagnosis and Management of Cytomegalovirus Infection in Pregnancy and Newborn. This guideline suggests the management of mother and child infection, its diagnostic and therapeutic options. Considers the global and Latin American epidemiology, with recommendations for clinical and laboratory evaluation,

Fecha de recepción: 09-12-2021

Fecha de aceptación: 09-12-2021

*Giannina Izquierdo

E-mail: gianninai@yahoo.es

DOI: 10.24875/RECHOG.M21000038

Disponible en internet: 07-02-2022 Rev Chil Obstet Ginecol. 2021;86(6):591-622

www.rechog.com 0048-766X / @ 2021 Sociedad Chilena de Obstetricia y Ginecología. Publicado por Permanyer. Éste es un artículo open access bajo la licencia CC BY-NC-ND (https://creativecommons.org/licenses/by-nc-nd/4.0/).
} 
Rev Chil Obstet Ginecol. 2021;86(6)

diagnostic criteria, therapeutic approaches according to the clinical situation, analyzes prevention measures and establishes a national proposal for monitoring this disease.

Keywords: Cytomegalovirus. Pregnancy. Newborn. Congenital infection. Prenatal diagnosis. SCORTCH.

\section{Introducción}

El citomegalovirus (CMV) es la causa más frecuente de infección congénita, con prevalencias que varían según la región y el nivel socioeconómico, siendo en general del $0,2 \%$ al $6 \%{ }^{1,2}$ alrededor del mundo. La infección fetal puede ocurrir por una primoinfección materna durante el embarazo o ser secundaria a una reactivación o reinfección viral (infección no primaria), con un riesgo de transmisión del $30 \%$ al $40 \%$ y del $1 \%$ al $2 \%$, respectivamente $^{3}$. El diagnóstico de infección por CMV congénita (CMVc) se realiza mediante la detección de ácidos nucleicos o aislamiento viral en orina (o en otros fluidos) antes de los 21 días de vida. El $90 \%$ de los recién nacidos (RN) con infección congénita son asintomáticos al nacer, y el $5 \%$ al $15 \%$ de ellos desarrollarán secuelas a largo plazo, como alteraciones del neurodesarrollo o hipoacusia sensorioneural, por lo que es fundamental un alto índice de sospecha ${ }^{4}$. El grupo de RN sintomáticos al nacer (10\%) desarrolla al menos una secuela en el $40 \%$ al $58 \%$ de los casos; la hipoacusia es la principal, constituyéndose el CMVc como el principal agente causal de sordera no genética en los niños. Esta puede diagnosticarse al nacer o desarrollarse durante la infancia, y aproximadamente el $50 \%$ de los niños con CMVc presentan deterioro o progresión de su trastorno auditivo, siendo fundamental el seguimiento a largo plazo de estos pacientes ${ }^{5,6}$.

Existen aún numerosos desafíos y controversias sobre el diagnóstico, la evaluación clínica, el tratamiento y el seguimiento de la infección por CMV, tanto en la mujer embarazada como en el RN. Estas recomendaciones están confeccionadas basándose en la evidencia científica disponible, consensuada con opiniones de expertos, y podrían variar en la evaluación caso a caso y en la medida en que se disponga de mayor evidencia. Se presentan como guías de manejo para facilitar el trabajo de los equipos de salud a cargo de la atención del binomio con infección por CMV.

\section{Definiciones operacionales}

En la tabla 1 se resumen las definiciones operacionales y los criterios diagnósticos de la infección por CMV en la mujer embarazada y en el RN.

\section{Historia natural}

\section{Seroprevalencia materna y riesgo de infección fetal}

La infección por CMV es frecuente en el mundo, con una prevalencia en la población general y materna del 83\% (intervalo de confianza del 95\% [IC95\%]: 78-88) y el $86 \%$ (IC95\%: 83-89), respectivamente. La variabilidad reportada depende de diversos factores, tales como la edad, la condición socioeconómica y cultural, la ubicación geográfica y el contacto cercano con niños. Es así como la seroprevalencia en las mujeres de edad fértil es del $50 \%$ al $70 \%$ en población europea y de América del Norte, y del $90 \%$ al $100 \%$ en Asia, África y América Latina ${ }^{1,7}$.

En Chile, la seroprevalencia en la mujer embarazada ha sido reportada por diversos autores, con valores que fluctúan entre el $92 \%$ y el $95 \% \%^{8,9}$. El último reporte es del año 2005, cuando se estudió la seroprevalencia de mujeres gestantes al momento del trabajo de parto en el área suroriente de Santiago, encontrando datos similares a los previos, con un $95 \%$ de mujeres seropositivas $^{10}$.

Como la relación entre la infección materna (primoinfección o infección no primaria) y las infecciones fetales se asocia con la tasa de seroprevalencia en las mujeres embarazadas ${ }^{3}$, en poblaciones con alta seroprevalencia $(\approx 90 \%)$ casi todas las infecciones fetales están relacionadas con infecciones maternas no primarias. Es así como, en Brasil, Mussi-Pinhata et al. ${ }^{11}$ reportaron una seroprevalencia materna del $98 \%$, y el $90 \%$ de las infecciones congénitas fueron secundarias a una infección materna no primaria, algo similar a lo que ocurre en nuestro país ${ }^{10}$. En países con seroprevalencia intermedia $(\approx 70 \%)$, como los Estados Unidos de América, el $75 \%$ de las infecciones congénitas estarían relacionadas con infecciones maternas no primarias $^{3}$. En países con baja seroprevalencia materna, como sucede en la mayoría de los países europeos ( $\approx 50 \%$ ), se espera una proporción igual entre las infecciones fetales relacionadas con la primoinfección materna y las relacionadas con la infección materna no primaria $^{3,12}$.

El riesgo de transmisión madre-feto depende del momento del embarazo en que ocurre la infección 
Tabla 1. Definiciones operacionales y criterios diagnósticos de la infección por CMV en la mujer embarazada y RN

\begin{tabular}{|c|c|c|}
\hline Concepto & Definición & Criterios diagnósticos \\
\hline $\begin{array}{l}\text { Primoinfección en } \\
\text { embarazo }\end{array}$ & $\begin{array}{l}\text { Primera exposición de una mujer embarazada } \\
\text { a CMV }\end{array}$ & $\begin{array}{l}\text { Seroconversión de IgG-CMV en una mujer previamente } \\
\text { negativa } \\
\text { IgG positiva + IgM positiva y baja avidez de } \lg G\end{array}$ \\
\hline $\begin{array}{l}\text { Infección no primaria } \\
\text { (Reactivación } 0 \\
\text { reinfección) }\end{array}$ & $\begin{array}{l}\text { Infección en la madre que ocurre teniendo } \\
\text { inmunidad previa. Puede ser una reactivación } \\
\text { de un virus endógeno o una reinfección } \\
\text { exógena por otra cepa viral. }\end{array}$ & $\begin{array}{l}\text { Tanto reactivación como reinfección pueden cursar con } \\
\text { IgG positiva/lgM positiva/ alta avidez de IgG }\end{array}$ \\
\hline Infección fetal & $\begin{array}{l}\text { Infección del feto, secundario a primoinfección } \\
\text { o infección no primaria materna }\end{array}$ & $\begin{array}{l}\text { Detección de RPC CMV en el líquido amniótico a través de } \\
\text { amniocentesis } y / 0 \text { RPC CMV y/o IgM en sangre fetal a } \\
\text { través de cordocentesis. }\end{array}$ \\
\hline CMV congénito & $\begin{array}{l}\text { Infección del RN que ocurre durante el } \\
\text { embarazo o parto }\end{array}$ & $\begin{array}{l}\text { RPC o aislamiento viral positivo en orina, sangre y/o LCR } \\
\text { antes de los } 21 \text { días de vida*. }\end{array}$ \\
\hline CMV postnatal & $\begin{array}{l}\text { Infección por CMV que ocurre durante } 0 \\
\text { después del parto. }\end{array}$ & $\begin{array}{l}\text { RPC positiva o aislamiento viral en orina, sangre y/o LCR } \\
\text { después de los } 21 \text { días de vida, con un estudio al nacer } \\
\text { negativo. } \\
\text { Si no se dispone de estudio de CMV al nacer, no es } \\
\text { posible diferenciar la infección congénita de la adquirida } \\
\text { en forma postnatal. }\end{array}$ \\
\hline
\end{tabular}

Abreviaturas: CMV: citomegalovirus; RPC: reacción de polimerasa en cadena; Ig: inmunoglobulina; LCR: líquido cefalorraquídeo

* En caso de detección en saliva se debe confirmar en orina.

materna. Es mayor cuanto más avanzado está el embarazo. El riesgo de infección fetal es casi inexistente si la madre adquiere la infección antes de las 12 semanas previas a la concepción ${ }^{13,14}$, del $5 \%$ si ocurre en el período preconcepcional (no superior a 12 semanas), y aumenta al $21 \%$ si la infección materna es periconcepcional (entendiendo este período como el comprendido entre las 4 semanas previas a la fecha de la última regla y las 5 semanas desde la concepción ${ }^{15}$ ), al $36 \%$ si es de primer trimestre, al $40 \%$ si es del segundo trimestre y al $66 \%$ en el tercer trimestre.

A su vez, el riesgo de compromiso fetal profundo y de secuelas es del $19 \%$ al $28 \%$ en las infecciones periconcepcionales y de primer trimestre, y casi inexistente si el feto adquiere la infección a partir de un cuadro materno de segundo $(0,9 \%)$ o tercer trimestre $(0,4 \%)^{16}$.

La transmisión del CMV hacia el feto ocurre por vía transplacentaria y se produce con mayor frecuencia después de una primoinfección. La tasa de primoinfección materna es del $1 \%$ al $8 \%$ en los países desarrollados $^{17,18}$, con un riesgo estimado de transmisión fetal del $30 \%$ al $40 \%{ }^{14}$. La tasa de infección materna no primaria es del $1 \%$ al $2 \%$ de las madres con inmunidad previa con un riesgo menor de transmisión al feto $(0,2-$ 3,4\%) ${ }^{14,19}$ (Fig. 1).

Tanto la primoinfección como la infección no primaria pueden generar compromiso fetal profundo y secuelas a largo plazo, si estas ocurren principalmente durante el primer trimestre del embarazo ${ }^{20,21}$. Pese a que la transmisión vertical es mayor en el caso de la primoinfección materna, proporcionalmente el número de casos de infección congénita en poblaciones de alta seroprevalencia ocurre sobre todo por una infección materna no primaria. La morbilidad fetal relacionada con la infección materna no primaria es tan alta como la relacionada con la primoinfección. En una serie de

\section{Puntos clave \#1}

- La infección congénita por CMV puede ocurrir tanto por primoinfección como por infección no primaria.

- En los países de alta seroprevalencia, como Chile, la mayoría de los casos de CMVc ocurren secundariamente a una infección no primaria.

- La transmisión vertical es mayor en la primoinfección que en las infecciones no primarias (30-40\% vs. $0,2-3,4 \%)$.

- Las secuelas son similares en la primoinfección y en la infección no primaria, por lo que el factor más importante de morbilidad fetal es el trimestre en que se produce la infección. Los casos graves ocurren casi exclusivamente secundarios a infección materna periconcepcional o del primer trimestre. 


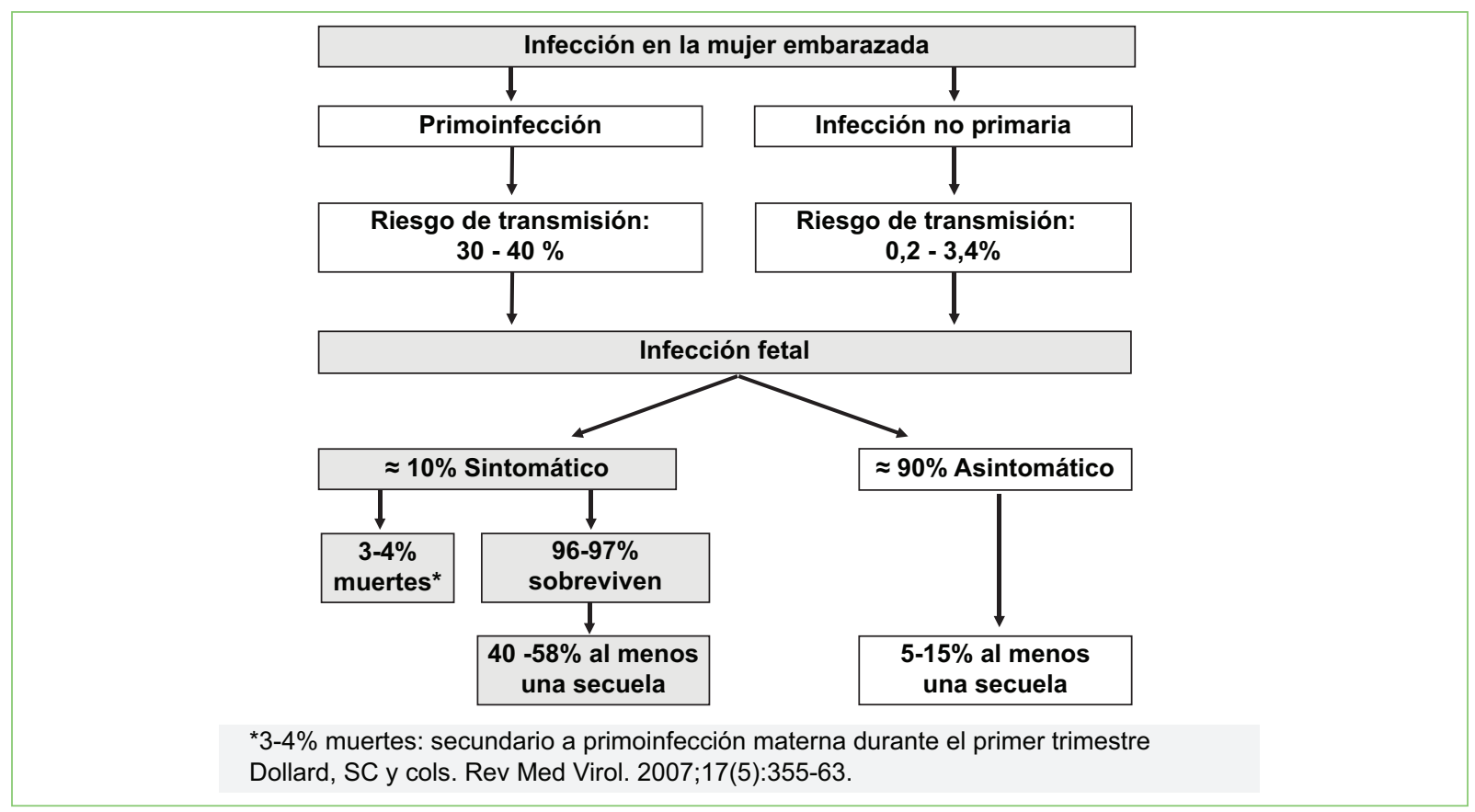

Figura 1. Riesgo de infección fetal y secuelas según el tipo de infección materna por CMV.

300 RN, 176 infectados después de una primoinfección materna y 124 después de una infección materna no primaria, la proporción de $\mathrm{RN}$ sintomáticos y de pérdida auditiva fue del $11 \%$ y el $10 \%$, respectivamente ${ }^{22}$. En un estudio de seguimiento, las infecciones maternas no primarias contribuyeron sustancialmente a la carga de enfermedad por CMVc en la infancia: la mitad de los niños que presentaban resultados moderados a graves nacieron de madres con infecciones no primarias ${ }^{23}$.

\section{Prevalencia de la infección congénita por CMV en el recién nacido}

La prevalencia de infección por CMV en el RN, o «carga de enfermedad", varía en función de la seroprevalencia y de la condición socioeconómica y cultural de la madre, con valores del $0,2 \%$ al $2 \%$ (promedio: $0,65 \%)^{1,2}$ a lo largo del mundo. Existe una gran heterogeneidad en los estudios realizados en países en vías de desarrollo ${ }^{24}$, con valores para Latinoamérica que fluctúan entre el $0,6 \%$ en Panamá ${ }^{25}$ y el 8,4\% en Colombia ${ }^{26}$. En Chile, la tasa de infección congénita por CMV fue reportada por Vial et al. ${ }^{8}$ y Luchsinger et al..$^{27}$, en las décadas de 1980 y 1990, con prevalencias del $1,7 \%$ y el $1,8 \%$, respectivamente, y no existen nuevos registros a la fecha del presente escrito.

Del total de los RN infectados, el $20 \%$ presenta secuelas neurológicas que pueden variar desde hipoacusia sensorioneural aislada hasta discapacidad intelectual o déficit motor a largo plazo, especialmente en infecciones ocurridas en el primer trimestre de gestación ${ }^{28}$. Un metaanálisis realizado por Dollard et al. ${ }^{29}$ analizó a 117.986 RN con cribado universal de CMV y encontró una prevalencia del $0,7 \%$. De ellos, el 12,7\% se catalogaron como sintomáticos al nacer, el $3 \%$ a $4 \%$ fallecieron y el $40 \%$ a $58 \%$ desarrollaron al menos una secuela a largo plazo. De los RN asintomáticos $(87,3 \%)$, el 13,5\% presentaron secuelas (Fig. 1).

La principal secuela atribuible a CMVc es la hipoacusia sensorioneural, presente en un $7 \%$ a $15 \%$ del total de los niños infectados, en el $30 \%$ al $60 \%$ de los RN sintomáticos y en el $5 \%$ al $10 \%$ de los asintomáticos. Sin embargo, la hipoacusia sensorioneural puede ser igualmente grave en ambos grupos, ser unilateral o bilateral, no estar presente al momento de nacer y evolucionar en el tiempo, por lo que requiere un seguimiento activo a largo plazo $^{30}$ (v. apartado "Seguimiento auditivo»). Se han estudiado otras secuelas neurocognitivas, como alteraciones motoras (espasticidad o paresias), epilepsia, retraso madurativo para la edad y coriorretinitis, con una frecuencia de más del $90 \%$ en los RN sintomáticos con microcefalia e hipoacusia profunda bilateral al nacer ${ }^{31}$. La frecuencia de alteraciones neurocognitivas tardías en los niños asintomáticos al nacimiento varía en los diferentes estudios. Algunos autores plantean que entre el 


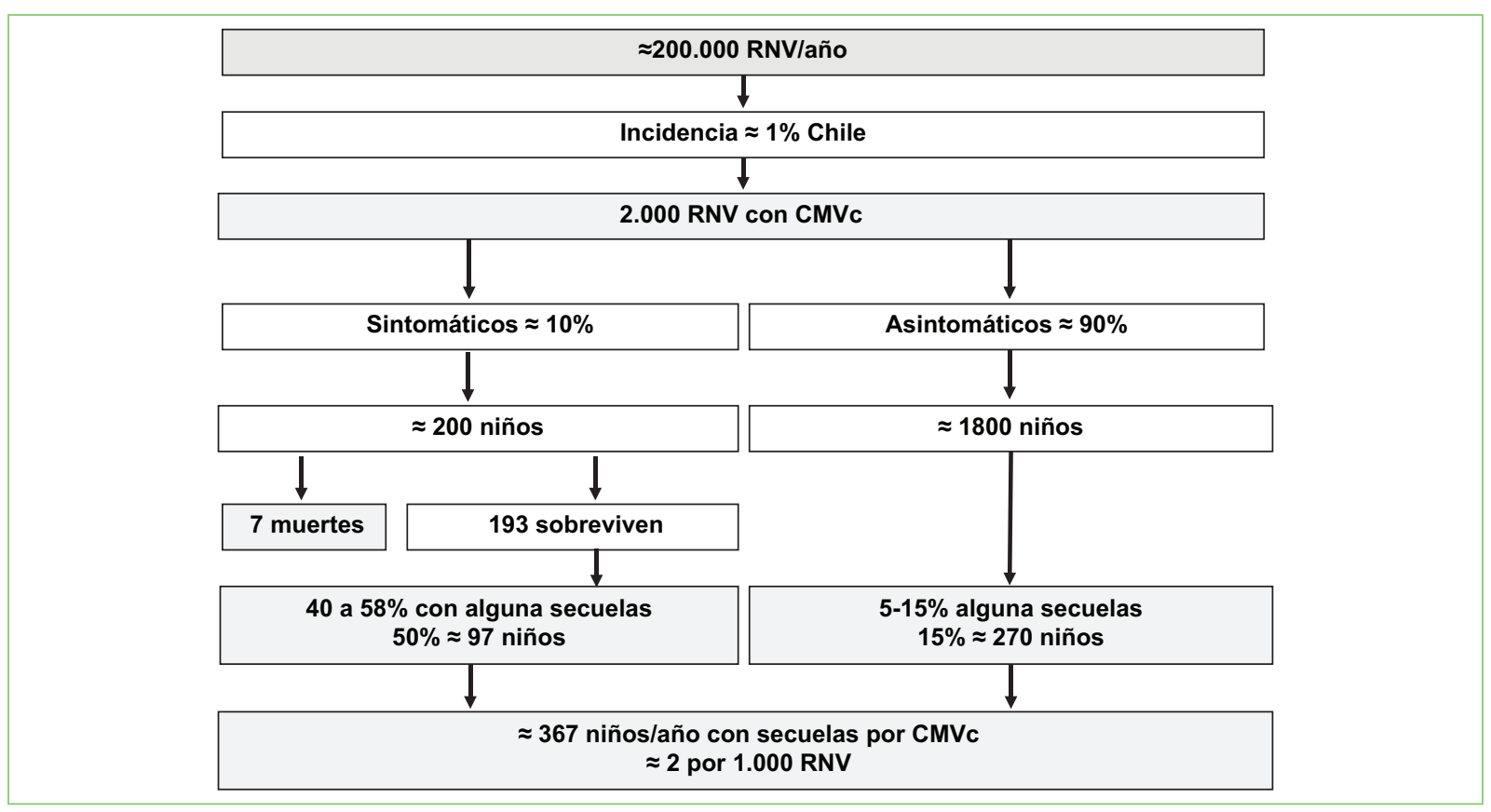

Figura 2. Estimación de la carga de enfermedad por CMVc en Chile.

$2 \%$ y el $7 \%$ de los niños asintomáticos al nacer presentarán microcefalia a los 2 años de vida, con un grado variable de afectación neurocognitiva $(5 \%)$ y de trastornos visuales $(2 \% \text { coriorretinitis })^{32}$.

Si se realiza una estimación de la prevalencia de CMVc nacional $(\approx 1 \%)$, con una cohorte de $\approx 200.000$ RN vivos (RNV) al año en nuestro país, habría alrededor de 2000 RNV en Chile con CMVc (frecuencia de 2 por 1000 RNV), y de ellos, 367 con al menos una secuela neurológica o auditiva por año ${ }^{33}$ (Fig. 2).

\section{Fisiopatología de la infección en el feto}

El antecedente de infección de la madre reduce parcialmente la posibilidad de infección fetal por CMV, pero no impide que el virus atraviese la placenta para infectar al feto ${ }^{34}$. La infección fetal se debe a la viremia materna con la consiguiente diseminación hematógena al feto; la mediana de tiempo entre la infección materna y la fetal es de unas 6 a 8 semanas ${ }^{21}$.

La inmunidad pasiva se confiere gracias a que los anticuerpos maternos atraviesan eficazmente la interfaz materno-fetal; sin embargo, en el caso del CMV, los anticuerpos pueden facilitar la transmisión de este virus a través de la barrera placentaria, ya que el CMV cruza la placenta a través de complejos IgG-virión utilizando el receptor Fc neonatal expresado en la superficie de los sincitiotrofoblastos. Si los complejos de
IgG-virión están formados por anticuerpos neutralizantes de alta avidez, estos pueden neutralizarse rápidamente por macrófagos de las vellosidades coriales en el lado fetal, mientras que los complejos de anticuerpos de baja avidez permiten que el virus escape de los macrófagos e infecte al feto. Por tanto, el momento de la infección en relación con el establecimiento del embarazo y la avidez del anticuerpo por el CMV son determinantes críticos en la protección fetal, ya que los anticuerpos de baja avidez pueden persistir 3 a 4 meses y esto puede ser una ventana de alto riesgo ${ }^{34}$.

La infección de las células placentarias por CMV contribuye a la patogenia al alterar la formación de la placenta, resultando en insuficiencia placentaria, de manera similar a lo que ocurre en la preeclampsia ${ }^{34}$. La infección del trofoblasto al comienzo de la gestación puede afectar la implantación adecuada y, por lo tanto, contribuir a la pérdida del embarazo. En las últimas etapas de la gestación, el desarrollo inadecuado de la placenta puede resultar en restricción del crecimiento fetal y patología placentaria, estando esta última fuertemente asociada a enfermedad fetal y neonatal ${ }^{34}$. Por lo tanto, algunas de las características clínicas de la infección por CMV podrían ser secundarias a la hipoxia fetal y a la hipoperfusión resultante de la insuficiencia placentaria, lo que a su vez podría contribuir a la patogenia de anomalías cerebrales como la polimicrogiria ${ }^{34}$. 


\section{Infección en la mujer embarazada}

\section{Diagnóstico clínico}

La mayoría de las infecciones por CMV en el adulto son asintomáticas, pero la primoinfección en el adulto joven puede producir un síndrome mononucleósico con fiebre, linfadenopatías y linfocitosis relativa. Frente a estos síntomas inespecíficos, es importante que se hayan descartado otras etiologías infecciosas para establecer un adecuado diagnóstico. Los síntomas más comunes son fiebre y mialgias, y se pueden asociar a hallazgos de laboratorio como linfocitosis (> $40 \%$ ) y alteración de las transaminasas. La combinación del cuadro clínico y las alteraciones de laboratorio se observa hasta en el $60 \%$ de las pacientes con primoinfección por CMV, comparada con el $20 \%$ en aquellas infecciones no primarias ${ }^{35}$.

\section{Diagnóstico de laboratorio}

\section{SEROLOGía}

El diagnóstico serológico de infección primaria se basa en la determinación de $\lg G$ e $\operatorname{lgM}$ :

- IgG: Ios anticuerpos de clase IgG pueden detectarse en el suero alrededor de las 3 semanas posteriores a la infección y, aunque su nivel declina, generalmente persisten en bajas concentraciones de por vida. Una determinación de IgG positiva puede significar una infección antigua resuelta o bien una reinfección o una reactivación. La seroconversión de $\lg \mathrm{g}$ a las 3-4 semanas es característica de la infección primaria, pero poco frecuente de pesquisar debido a la falta de cribado de anticuerpos preconcepcionales. Los estudios han observado que el seguimiento con títulos de IgG no suele lograr determinar el momento de la infección, pues en la mayoría de los casos ya se ha alcanzado el plateau en la primera determinación ${ }^{36}$. Es importante considerar que, si bien la sensibilidad y la especificidad de la IgG son altas (97-100\%), tiene una baja concordancia entre los diferentes tipos de test comerciales, por lo que no se deben comparar determinaciones realizadas con distintas técnicas de laboratorio ${ }^{37}$.

- IgM: en las personas inmunocompetentes, los anticuerpos séricos de clase lgM frente al CMV son detectables 7-12 días después de la infección primaria, tardan 2-3 semanas en alcanzar su nivel máximo y luego disminuyen hasta ser indetectables unos meses más tarde. Su positividad en el embarazo debe alertar de una infección reciente, una reactivación o una reinfección. No obstante lo anterior, una IgM positiva en el embarazo puede persistir positiva por un largo período (hasta 6-12 meses) o tratarse de una reacción cruzada frente a otros virus (Epstein Barr, herpes simple o varicela-zóster) o enfermedades autoinmunitarias. Su sensibilidad es del $80 \%$ al $100 \%$, su especificidad fluctúa entre el $60 \%$ y el $100 \%$, y se debe complementar con IgG para su interpretación ${ }^{38}$.

Los posibles escenarios serológicos y su interpretación son:

- IgG positiva e IgM negativa: infección antigua o reinfección reciente en la que aún no se positiviza la $\operatorname{lgM}(<2$ semanas). Considerar repetir solo según sospecha clínica materna o hallazgos ecográficos sugerentes.

- IgG negativa e IgM positiva: resultado falso positivo de IgM o primoinfección en la que aún no se positiviza la IgG (< 4 semanas). Se recomienda repetir la IgG en 3-4 semanas para evaluar la seroconversión materna. En caso de persistir una IgG negativa, considerar falso positivo de IgM. Si la IgG se positiviza, se considera primoinfección.

- IgG positiva e IgM positiva: primoinfección o reinfección. Realizar test de avidez (para excluir o confirmar la infección reciente) o, en su defecto, reacción en cadena de la polimerasa (PCR, polimerase chain reaction) para CMV en sangre materna.

\section{TEST DE AVIDEZ}

Se recomienda realizar si tanto la IgG como la IgM son positivas, ya que es útil para diferenciar la primoinfección de la infección no primaria. Los anticuerpos con baja avidez son más fácilmente disociados del complejo que aquellos con alta avidez; un test de baja avidez indica infección reciente (últimos 3-4 meses), y uno con alta avidez indica infección antigua ( $>5$ meses). Los valores para definir alta o baja avidez dependen del test comercial, pero se reconoce una avidez baja cuando es $<35-40 \%$ y se considera alta cuando es $>60 \%$. De acuerdo con la evidencia actual, su realización es fundamental dentro del flujograma de estudio de la infección en la mujer embarazada, por lo que se debería incorporar este examen en nuestro país a gran escala, ya que hasta ahora no está disponible ${ }^{39}$.

Se debe tener presente que la avidez puede ser falsamente baja en infecciones pasadas con IgG muy bajas y falsamente alta en conversiones muy recientes. Una avidez intermedia (40-60\%) en el primer trimestre del embarazo no puede descartar la ocurrencia de una infección primaria en el embarazo temprano o en el 


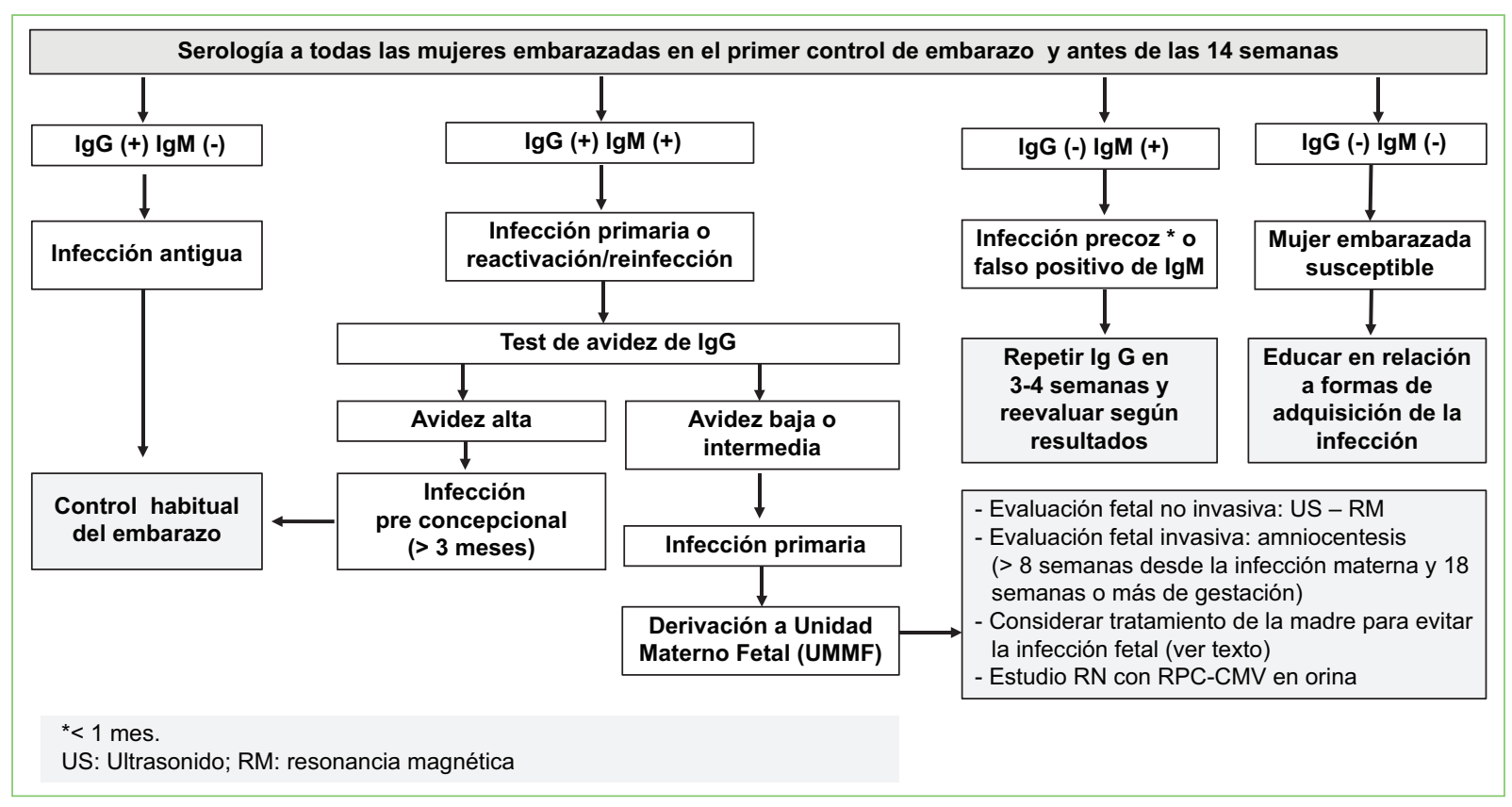

Figura 3. Escenario estudio de citomegalovirus con cribado universal en el primer trimestre del embarazo.

período preconcepcional, y podría tener especial importancia durante el cribado de primer trimestre, dado que puede corresponder a una infección periconcepcional (5-20\% de riesgo de transmisión vertical) $)^{16,40}$ o a una infección que ocurrió varias semanas antes en el período preconcepcional, con un riesgo mínimo de transmisión al feto. Ante esa situación, una PCR-CMV positiva en sangre materna se asocia a un aumento en el riesgo de transmisión vertical ${ }^{41,42}$, por lo que, combinada con un test de avidez intermedio, podría requerir manejo y seguimiento equivalentes a los de la paciente con avidez baja.

\section{PCR-CMV EN SANGRE MATERNA}

Es importante considerar que el CMV es un virus inmunomodulador que puede ser detectado en sangre mediante PCR en forma concomitante con otras infecciones, especialmente virales. Por otra parte, no existen puntos de corte definidos de la PCR-CMV cuantitativa para establecer una infección activa, y el diagnóstico por PCR no está validado como técnica diagnóstica para CMV en el embarazo. Sin embargo, en algunos casos de complejidad diagnóstica podría ser una herramienta cuyo resultado debe ser interpretado caso a caso ${ }^{43}$. Se debe realizar en sangre total y en tubo con anticoagulante (EDTA).
Recomendación \# 1: diagnóstico de la infección materna

- El diagnóstico de infección primaria en el embarazo se puede realizar con:

a)Seroconversión de IgG específica en paciente previamente negativa 0

b) Detección de IgM positiva con avidez de IgG baja (recomendación fuerte, alta calidad de evidencia).

- El diagnóstico de la infección materna no primaria es difícil y se basa principalmente en la combinación de una IgG positiva, una IgM positiva y un test de avidez alto (recomendación débil, baja calidad de evidencia).

- La interpretación de una PCR-CMV positiva en sangre materna debe ser individualizada, ya que aún no está validada ni existen puntos de corte (PCR-CMV cuantitativa) definidos para el embarazo (recomendación débil, muy baja calidad de evidencia).

\section{Infección fetal}

\section{Evaluación de la infección fetal}

Desde el punto de vista clínico, existen dos escenarios diferentes en la evaluación de la infección fetal, dependiendo de si se está en un centro que realiza cribado universal (no disponible en la actualidad en Chile y realizado en países con baja seroprevalencia) 


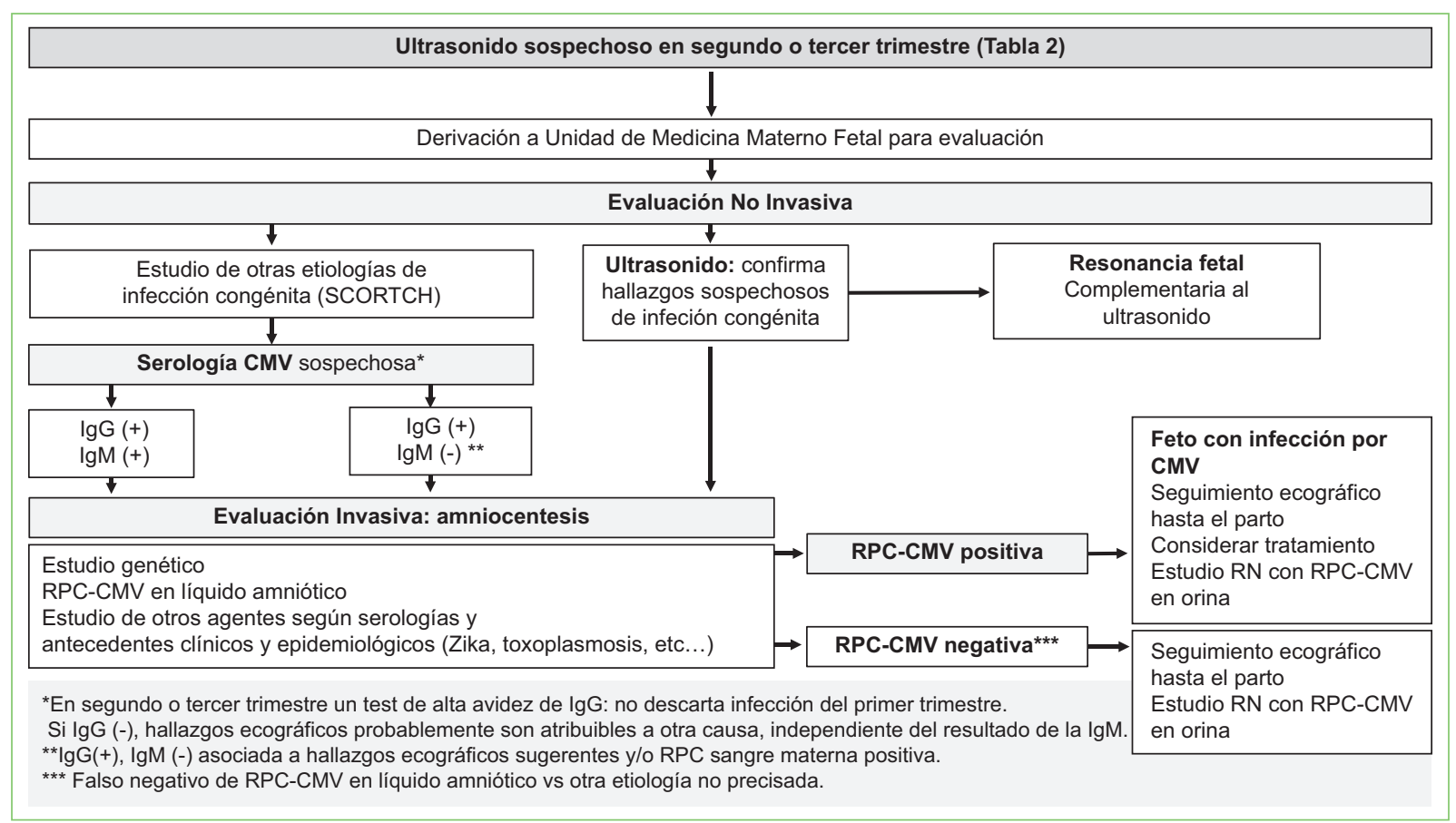

Figura 4. Escenario de estudio diagnóstico según hallazgo en ultrasonido fetal, sin cribado universal en la mujer embarazada.

o si se estudia frente a alteraciones morfológicas pesquisadas en una ecografía durante el control prenatal, situación más frecuente en nuestro país.

En el primer escenario (Fig. 3), la estrategia de tamizaje está orientada a identificar la primoinfección materna en el primer trimestre $o$ en el período periconcepcional mediante IgG/lgM de CMV y test de avidez de IgG cuando corresponde (solicitando examen serológico en el primer control de embarazo).

Frente a la infección materna detectada por serología, según los criterios descritos previamente, la paciente deberá ser evaluada en un centro de medicina materno-fetal con estudio invasivo (amniocentesis) para confirmar o descartar la infección fetal y con estudio no invasivo (ultrasonido o resonancia magnética [RM]) en búsqueda de hallazgos sugerentes de compromiso fetal. Todas las madres con primoinfección deben ser seguidas hasta el parto y hay que considerar el tratamiento para evitar la infección fetal (v. apartado «Prevención de la infección fetal»).

En el segundo escenario (Fig. 4), cuando no se realiza cribado universal (situación actual en Chile), la sospecha y el estudio de infección por CMV surgen cuando la ecografía detecta alteraciones sugerentes de compromiso fetal (Tabla 4); por lo tanto, solo se pesquisan los casos más graves de infección fetal y habrá niños infectados no pesquisados al nacer (ultrasonido prenatal y examen físico neonatal normales) que presentarán secuelas tardías.

Los hallazgos imagenológicos no son específicos para la infección por CMV, por lo que el médico clínico deberá realizar el diagnóstico diferencial con otras infecciones congénitas. Para ello, se debe realizar una adecuada anamnesis (síntomas maternos sugerentes, antecedentes epidemiológicos de viajes, contacto con niños menores de 6 años, vacunas, consumo de carne parcialmente cocida y contacto con animales) y solicitar el estudio serológico para las etiologías más probables. Una forma de abordarlo es mediante el acrónimo SCORTCH (Syphilis, Cytomegalovirus, Other [p. ej., Zika], Rubella, Toxoplasmosis, Chickenpox, Herpes simplex virus), que permite un enfrentamiento racional según los hallazgos encontrados ${ }^{44,45}$. Se descartarán las etiologías para las que el resultado de lgG es negativo (y la sífilis si el test no treponémico es negativo), y entrarán en el diagnóstico diferencial las etiologías para las que la madre es IgG positiva, incluso si la lgM es negativa o la avidez es alta, dado que nos enfrentamos a un escenario en que el feto ya está comprometido y el embarazo está más avanzado. Esto se explica porque pueden haber pasado varios meses entre el momento de la infección materna (período 
Tabla 2. Alteraciones ecográficas fetales relacionadas con CMVc

\begin{tabular}{|c|c|c|}
\hline Alteraciones graves del SNC & Alteraciones leves del SNC & Alteraciones extracerebrales \\
\hline Ventriculomegalia $>15 \mathrm{~mm}$ & Ventriculomegalia $>10 y<15 \mathrm{~mm}$ & Hepatomegalia (lóbulo derecho $>40 \mathrm{~mm}$ ) \\
\hline Hiperecogenicidad periventricular & Adherencias intraventriculares & $\begin{array}{l}\text { Intestino hiperecogénico } \\
\text { (ecogenicidad igual o mayor a hueso) }\end{array}$ \\
\hline Dilatación tri o cuadriventricular & Calcificaciones intracerebrales & $\begin{array}{l}\text { Esplenomegalia } \\
\text { (diámetro mayor }>40 \mathrm{~mm} \text { en segundo trimestre) }\end{array}$ \\
\hline Microcefalia $P C<2$ DS & Quistes subependimarios & Restricción crecimiento fetal \\
\hline Cisterna magna $>8 \mathrm{~mm}$ & Quistes plexos coroideos & Oligoamnios \\
\hline Hipoplasia de vermis & $\begin{array}{l}\text { Calcificaciones de los vasos lenticuloestriados } \\
\text { en los ganglios basales }\end{array}$ & Polihidroamnios \\
\hline \multirow[t]{5}{*}{ Porencefalia } & & Ascitis \\
\hline & & Derrame pleural \\
\hline & & Hidrops \\
\hline & & Placentomegalia $>40 \mathrm{~mm}$ \\
\hline & & Calcificaciones hepáticas/quiste hepático \\
\hline
\end{tabular}

SNC: sistema nervioso central. PC: perímetro cefálico

Adaptado de : Leruez-Ville M, Ville Y. Fetal cytomegalovirus infection. Best Pract Res Clin Obstet Gynaecol. 2017; 38: 97-107

periconcepcional o primer trimestre) y la evaluación diagnóstica. El estudio invasivo podría confirmar el agente infeccioso causal de las alteraciones ecográficas detectadas, y ofrecer así terapia (según el agente específico y la evidencia disponible) y seguimiento. Habitualmente se incluye, además, un estudio genético fetal en el líquido amniótico, dado que las alteraciones ecográficas sospechosas de SCORTCH también pueden asociarse a alteraciones cromosómicas.

\section{Puntos clave \# 2}

- La evaluación y el manejo de la infección prenatal dependerán de si se encuentra en un escenario de cribado universal o si se pesquisa a partir de un ultrasonido fetal alterado.

- Los hallazgos de las imágenes fetales no son específicos de infección por CMV, por lo que se deben descartar otras etiologías (infecciosas o no infecciosas).

\section{Evaluación fetal no invasiva: imágenes}

\section{ULTRASONOGRAFÍA FETAL}

El examen ultrasonográfico es fundamental en el proceso diagnóstico y de manejo de la infección fetal por CMV. El rendimiento de la ecografía para detectar infección fetal y riesgo de secuelas varía dependiendo del escenario donde se está haciendo el examen. En una situación de control prenatal sin tamizaje serológico universal, el ultrasonido es capaz de detectar solo el $25 \%$ de los casos en que habrá un feto infectado que desarrollará secuelas graves, por lo que no es una buena herramienta de pesquisa de niños con riesgo de secuelas a largo plazo. En cambio, cuando se conoce la condición de infección fetal, el ultrasonido alcanza una sensibilidad del $91 \%$ y un valor predictor negativo (VPN) del 96\% para la detección de fetos con secuelas a largo plazo ${ }^{46}$.

Es importante tener en consideración que las alteraciones en las imágenes fetales pueden demorar 12 semanas o más en aparecer luego de la infección materna ${ }^{47}$. Los hallazgos ecográficos se clasifican en alteraciones del sistema nervioso central (SNC) y alteraciones extracerebrales, tal como se muestra en la tabla 2. Pueden ser evolutivos a lo largo del tiempo, ya sea alteraciones leves que luego desaparecen o, por el contrario, que evolucionan hacia un compromiso más profundo. Por ello, el seguimiento ultrasonográfico debe mantenerse hasta el parto ${ }^{48}$.

Existe más probabilidad de que se desarrollen lesiones cerebrales fetales en el contexto de una infección materna de primer trimestre ${ }^{49}$. Si el compromiso fetal es con lesiones cerebrales leves y aisladas, el pronóstico es similar al de los RN asintomáticos, con buena 
evolución, sin poder descartar la posibilidad de hipoacusia sensorioneural.

Las alteraciones de la migración neuronal, de difícil diagnóstico ultrasonográfico, son más factibles de estudiar en neurosonografía por vía vaginal, demostrando una pobre y asimétrica giración para una edad gestacional determinada, principalmente en relación a la cisura de $\mathrm{Silvio}^{40}$. La polimicrogiria y la heterotopía son hallazgos mejor pesquisados en la RM fetal.

Las lesiones extracerebrales fetales pueden ser evolutivas en el tiempo, por lo que el seguimiento seriado de un caso sospechoso o confirmado es fundamental. Se puede observar hepatoesplenomegalia. El lóbulo derecho hepático puede medirse en un plano parasagital entre el diafragma y la vesícula biliar ${ }^{50}$. El compromiso inflamatorio intestinal, con o sin perforación, puede manifestarse como intestino hiperecogénico. Se pueden producir íleo meconial o peritonitis meconial con ascitis asociada. La restricción del crecimiento fetal, con Doppler normal, también puede ser una de las manifestaciones. Se ha descrito cardiomegalia, que pudiera ser multifactorial (anemia, miocarditis o ambas) y también asociarse a efusión pericárdica o pleural; el hidrops, sin embargo, es infrecuente ${ }^{40}$.

La placenta puede actuar como reservorio, y como barrera, para la infección fetal, lo que explicaría por qué no toda infección materna produce infección fetal. Algunos estudios han reportado compromiso placentario que puede anteceder al compromiso fetal ${ }^{51}$. El crecimiento anormalmente grande (placentomegalia) se ha asociado a infección intrauterina. Si bien existen tablas de grosor placentario según la edad gestacional, son poco utilizadas en la práctica clínica. El grosor normal en la segunda mitad del embarazo es de 2 a $4 \mathrm{~cm}$ en la zona central ${ }^{52}$.

\section{RM FETAL}

Por tratarse de una técnica no invasiva y que no utiliza radiación ionizante, el uso de la RM durante la vida fetal ha sido creciente. En pacientes con sospecha o diagnóstico confirmado de infección por CMV, su indicación como examen complementario al ultrasonido ha demostrado utilidad, tanto en el diagnóstico de alteraciones como en su evaluación pronóstica.

El estudio del cuerpo completo del feto permite la evaluación de alteraciones dentro y fuera del SNC. Las secuencias potenciadas en T2 permiten objetivar la mayor parte de las alteraciones anatómicas, evidenciando precozmente microcefalia, microencefalia, dilatación del sistema ventricular o la presencia de quistes subependimarios en la evaluación del encéfalo, así como la presencia de líquido pleural, pericárdico, peritoneal o subcutáneo en las imágenes del tronco fetal. Las secuencias potenciadas en T1 permiten visualizar calcificaciones y focos de hemorragia en el parénquima cerebral, así como evaluar una posible hepatomegalia y alteraciones intestinales.

Varios autores reportan mayor sensibilidad en la detección de alteraciones con RM fetal sobre el ultrasonido. Doneda et al. ${ }^{53}$, por ejemplo, señalan una diferencia del $88 \%$ frente al $33 \%$ para pacientes sintomáticos en el período neonatal. Cambios en la señal del parénquima cerebral, con aumento de la intensidad de los lóbulos temporales y occipitales, anomalías del desarrollo cortical o hipoplasia cerebelosa, son hallazgos detectados con mayor facilidad con RM.

Faure-Bardon et al. ${ }^{49}$ evidenciaron una discordancia entre el ultrasonido y la RM, encontrando en el $26 \%$ de las ecografías normales alteraciones en la RM. Por ello, estos autores concluyen que la evaluación pronóstica por ultrasonido en serie, después de una infección fetal por CMV en el primer trimestre, mejora con la RM a las 32 semanas, y la utilización combinada de ultrasonido y RM podría predecir el riesgo de secuelas en un 35\% de los embarazos.

Considerando el pequeño tamaño de las estructuras y la resolución de las imágenes necesarias para hacer un diagnóstico, la RM fetal se recomienda a partir del segundo trimestre. Cannie et al..$^{54}$ demostraron que los estudios realizados entre las 27 y 33 semanas de gestación fueron igualmente confiables para predecir la hipoacusia sensorioneural y el deterioro neurológico. Averill et al. ${ }^{55}$, al estudiar la correlación entre los hallazgos prenatales y posnatales, concluyeron que la RM fetal durante el tercer trimestre entrega imágenes suficientemente detalladas como para evitar el estudio con RM durante el período de RN inmediato, y la necesidad, en algunos casos, de sedación. Aunque no es una herramienta muy disponible en nuestro país, técnicamente es un estudio factible con los equipos de RM instalados, tanto en servicios públicos como en centros privados. Teniendo en cuenta estas consideraciones, la evaluación con RM podría tener su mayor beneficio, sobre todo en nuestro medio, a partir de las 32 semanas de gestación, como opción complementaria en la evaluación de la afectación fetal.

\section{Evaluación invasiva}

\section{ESTUdIO DEL LÍQUIDO AMNIÓTICO Y LA SANGRE FETAL}

Amniocentesis: Este procedimiento invasivo pretende detectar por PCR la presencia de CMV en el 
líquido amniótico. El riesgo de pérdida fetal asociado al procedimiento se estima en un $0,1-0,2 \%$, de acuerdo con una revisión sistemática que evaluó estudios que incluyeron, principalmente, amniocentesis realizadas durante el segundo trimestre ${ }^{56}$.

Teniendo en consideración la latencia entre la infección materna y el eventual compromiso fetal, y la capacidad de excretar virus a través de la orina fetal, los dos elementos más importantes para planificar la amniocentesis son: 1) el intervalo entre la infección materna y la punción, y 2) la edad gestacional.

Si se conoce el momento de adquisición de la infección por parte de la madre (ya sea por estudio serológico o por cuadro clínico sugerente), deben pasar 8 semanas desde la fecha estimada de infección materna y la amniocentesis ${ }^{40,57}$. En relación con la edad gestacional mínima para tener una adecuada pesquisa, y reducir los falsos negativos, tradicionalmente se ha descrito a partir de las 21 semanas de embarazo. Sin embargo, un estudio evaluó el rendimiento de realizar amniocentesis en forma más precoz, comparando prospectivamente la amniocentesis a las $17-20$ semanas +6 días frente a 21-22 semanas + 6 días de gestación, y encontró que la amniocentesis precoz tuvo una sensibilidad del $95,8 \%$ con un VPN del $97,7 \%$, similares a los de la amniocentesis «tradicional» (sensibilidad del $91,5 \%$ y VPN del $82 \%)^{57}$. De acuerdo con estos resultados, los expertos recomiendan considerar, para realizar la amniocentesis, que hayan transcurrido al menos 8 semanas desde la infección materna y más de 17 semanas de edad gestacional ${ }^{40}$.

Varios estudios han evaluado la relación entre la carga viral en el líquido amniótico y la probabilidad de que el feto y el RN sean sintomáticos ${ }^{58-60}$. Si bien la mediana de la carga viral tiende a ser más alta en los niños afectados, la dispersión y la superposición son amplias, por lo que hoy en día su utilización como factor pronóstico no es universalmente aceptada.

La carga viral tiende a aumentar con la edad gestacional al momento de la amniocentesis, lo que se ha interpretado como una consecuencia de la excreción fetal de CMV a través de la orina y su consecuente acumulación en el líquido amniótico.

Sin embargo, algunos centros la han utilizado dentro del contexto de investigación en terapia prenatal como uno de los elementos para seleccionar fetos con alto riesgo de secuelas, a quienes ofrecer intervenciones terapéuticas. Se ha publicado un pequeño estudio en 15 mujeres embarazadas con infección fetal a las que se ofreció terapia combinada (valaciclovir [VACV] e inmunoglobulina); la selección de pacientes se hizo cuando había alteraciones cerebrales fetales o carga viral sobre 100.000 copias/ml en el líquido amniótico ${ }^{61}$.

\section{Cordocentesis}

La cordocentesis es un procedimiento invasivo que permite detectar por PCR la presencia de CMV en sangre fetal. Algunos parámetros bioquímicos de la sangre fetal, como plaquetopenia $\left(<100.000 / \mathrm{mm}^{3}\right)$, elevación de la alanina aminotransferasa $(>80 \mathrm{Ul} / \mathrm{ml})$, aumento de la bilirrubina directa $(>4 \mathrm{mg} / \mathrm{dl})$ y aumento de la B-2microglobulina (> $5 \mathrm{mg} / \mathrm{l})$, se han asociado a un mal resultado perinatal en caso de infección por CMV. También se ha descrito mayor riesgo de RN sintomático en caso de IgM positiva y carga viral $>30.000$ copias/ $\mathrm{ml}^{62}$. Como parámetros individuales, una mejor correlación con la gravedad del compromiso fetal es el recuento de plaquetas en sangre. La plaquetopenia es significativamente más frecuente en los RN con estudios de imágenes cerebrales anormales, con una odds ratio (OR) de 2,4 (IC: 1,3-4,5 ${ }^{63}$. Sin embargo, un análisis multiparamétrico, de estos elementos y otros que actualmente están en investigación, podría acercarse mejor a poder dar índices pronósticos frente a la infección fetal. Por el momento, no hay una indicación para realizar cordocentesis por esta patología, dado el riesgo de pérdida fetal asociado al procedimiento (1-2\%).

\footnotetext{
Recomendación \# 2: diagnóstico etiológico de la infección fetal

- Se recomienda realizar amniocentesis en búsqueda de infección fetal por CMV frente a una infección materna confirmada o frente a hallazgos ultrasonográficos sugerentes (recomendación fuerte, alta calidad de evidencia).

- Debe haber un intervalo de 8 semanas desde la infección materna (si es posible determinarlo), y el procedimiento debe realizarse después de las 17 semanas de gestación (recomendación fuerte, baja calidad de evidencia).

- La infección fetal se confirma con la detección de ADN del CMV por PCR en líquido amniótico (recomendación fuerte, moderada calidad de evidencia); no se recomienda la PCR-CMV cuantitativa, ya que no se correlaciona con el pronóstico fetal.
}

\section{Tratamiento de la mujer embarazada}

El tratamiento de la mujer embarazada con infección por CMV es aún tema de discusión. Se podría plantear 
como prevención de la transmisión fetal en una madre con primoinfección detectada a través del tamizaje del primer trimestre o como el tratamiento de un feto con infección confirmada.

\section{Prevención de la infección fetal}

\section{INMUNIZACIÓN PASIVA CON IG HIPERINMUNE ESPECIFIICA DE CMV}

La utilidad de la Ig hiperinmune específica para CMV en la prevención de la infección se sustenta en que la presencia de anticuerpos neutralizantes disminuiría el paso de CMV por la placenta, debido a la alta concentración y la avidez de los anticuerpos de la IgG-CMV y el efecto inmunomodulador frente a la inflamación placentaria y de los órganos fetales generada por el $\mathrm{CMV}^{64,65}$. Un estudio no aleatorizado que utilizó Ig-CMV en dosis de $100 \mathrm{U} / \mathrm{kg}$ por vía intravenosa mensualmente reportó una disminución significativa de la transmisión fetal entre madres no tratadas $(40 \%)$ y las que recibieron la intervención (16\%) ${ }^{65}$. Sin embargo, otros dos estudios aleatorizados, controlados con placebo, en infección primaria, no confirmaron estos hallazgos. El primero incluyó 123 mujeres embarazadas ${ }^{66}$ y el segundo se planificó para incluir 800 pacientes, pero fue interrumpido con la mitad de las madres reclutadas, sin encontrar diferencias en la tasa de infección fetal ${ }^{67}$; sin embargo, ambos utilizaron dosis consideradas bajas y en intervalos de tiempo más largos (100 U/kg cada 4 semanas).

Otra línea de investigación con Ig-CMV modificó la dosis y el intervalo de administración (200 U/kg y administración quincenal), considerando que la vida media de la Ig-CMV en la mujer embarazada es menor que la habitual (11 vs. 22 días) ${ }^{68}$, además de hacer énfasis en seleccionar solo embarazadas con primoinfección durante el primer trimestre, pensando en que la viremia y la invasión placentaria pueden ser muy precoces, incluso antes de que aparezcan los anticuerpos generados por la madre. Este estudio, no aleatorizado, demostró una transmisión vertical del 7,5\%, comparado con el $35 \%$ en un grupo control histórico ${ }^{69}$.

Posteriormente, en un nuevo estudio retrospectivo no aleatorizado realizado por Nigro et al. ${ }^{70}$, se encontraron diferencias significativas en la transmisión fetal en el grupo que recibió Ig-CMV en comparación con el grupo sin Ig-CMV ( $30 \%$ vs. $56 \% ; p<0,0001)$, con dosis altas y cada 2 semanas. A su vez, evaluaron los síntomas presentes en el RN y las secuelas a largo plazo. Un $0,7 \%$ de los RN presentó síntomas al nacer con el uso
Ig-CMV, en comparación con el 18\% sin su uso ( $p<0,001)$, y secuelas a largo plazo mayores al no recibir Ig-CMV $(p=0,001)$. De acuerdo con estos datos y el conocimiento del comportamiento farmacocinético de la Ig-CMV en la embarazada, sería importante realizar un estudio aleatorizado utilizando dosis más altas y más frecuentes, ya que probablemente esto sería un componente crítico para una terapia eficaz.

Kagan et al. ${ }^{71}$, continuando con su línea de investigación, concluyeron en un estudio observacional (extensión del estudio del año 2019) que la tasa de transmisión fue del 6,5\%, pero la Ig-CMV se utilizó en un grupo bien restringido: mujeres gestantes con primoinfección hasta las 14 semanas y dosis de Ig-CMV de $200 \mathrm{UI} / \mathrm{kg}$ por vía intravenosa cada 2 semanas y hasta las 18 semanas. No encontraron diferencias en cuanto a parto prematuro, preeclampsia y feto pequeño para la edad gestacional (PEG) en comparación con los datos de la población general.

En suma, la utilización de lg-CMV para la prevención de la infección fetal debería ser considerada frente a la primoinfección comprobada en el primer trimestre, en forma precoz, con dosis elevadas y cada 2 semanas durante la primera mitad del embarazo (hasta la amniocentesis), dentro del contexto de protocolos de investigación hasta que no se cuente con mayor evidencia sobre su eficacia.

\section{UTILIDAD DE LOS ANTIVIRALES}

Entre las opciones para tratar las enfermedades por CMV se incluyen los análogos de nucleósidos, ganciclovir (GCV), su prodroga valganciclovir (VGCV), y cidofovir, así como el análogo del pirofosfato de foscarnet $^{72}$. Más recientemente han aparecido otros antivirales, como el brincidofovir, el letermovir y el maribavir ${ }^{73}$. Todos ellos inhiben la síntesis de ADN viral, pero en general el GCV y el VGCV son los fármacos de elección.

En el embarazo, las alternativas se reducen debido al riesgo de teratogenicidad, por lo que se han estudiado in vitro e in vivo ${ }^{74}$ otros antivirales con alto perfil de seguridad, como el aciclovir (ACV) y su prodroga el valaciclovir (VACV). La actividad antiviral in vitro (medida como concentración inhibitoria del $50 \%$ ) de ACV/VACV es francamente inferior que la de los otros antivirales frente al CMV, por lo que se requieren dosis altas de ACV/VACV para lograr un efecto adecuado ${ }^{75}$.

El GCV y su prodroga oral VGCV son los antivirales más eficaces en el tratamiento del CMV, pero tienen una alta genotoxicidad in vitro, por lo que se han 
clasificado como potencialmente teratogénicos, ambos con categoría $C$ de la Food and Drug Administration (FDA). No hay datos a la fecha de su uso para evitar la infección fetal.

El ACV y el VACV tienen un perfil de seguridad adecuado para su uso durante el embarazo (categoría B de la FDA), con una tasa de malformaciones fetales equivalente a la de la población general ${ }^{76}$. Según la experiencia in vitro ${ }^{75} \mathrm{e}$ in vivo del uso de dosis altas de ACV/VACV para el tratamiento de la infección por CMV en otras poblaciones ${ }^{77}$, se realizó un estudio doble ciego, aleatorizado, controlado con placebo, que utilizó en 45 mujeres embarazadas VACV a dosis de $8 \mathrm{~g}$ al día (8 cápsulas de $500 \mathrm{mg}$ cada $12 \mathrm{~h}$ ) con el objetivo de prevenir la transmisión materno-fetal en caso de que se documentara una seroconversión durante el período periconcepcional o en el primer trimestre de gestación. Desde ese momento se iniciaba el tratamiento y se mantenía hasta la amniocentesis diagnóstica (aproximadamente a las 21 semanas de gestación). La infección fetal diagnosticada por amniocentesis positiva fue significativamente menor $(11 \%)$ en el grupo de tratamiento en comparación con el grupo que recibió placebo (29\%) (OR: 0,29; IC: 0,09-0,9) Los efectos secundarios descritos fueron náuseas $(29 \%)$, cefalea $(20 \%)$, dolor abdominal $(9 \%)$ y trombocitopenia (2\%); sin embargo, ninguna mujer gestante requirió la suspensión del tratamiento.

A su vez, datos preliminares de Faure-Bardon et al. (comunicación oral en ESPID 2021) en madres con primoinfección en el primer trimestre demostraron que la tasa de infección fetal es significativamente menor con el uso de dosis altas de VACV. La infección fetal en el grupo control fue del $29 \%$, frente al $12 \%$ en el grupo tratado con VACV $(p=0,029)$. Los resultados son similares a los reportados previamente por ShaharNissan et al. ${ }^{78}$, pero alertan de dos casos de falla renal aguda en 50 pacientes tratadas con la dosis de $4 \mathrm{~g}$ cada 12 horas y ningún caso en 172 pacientes con la dosis fraccionada cada 6 horas $(p=0,009)$. Los autores recomiendan utilizar dosis más frecuentes $(2 \mathrm{~g}$ cada 6 h), hidratar y monitorizar la función renal semanalmente en las pacientes en tratamiento con dosis altas de VACV.

En suma, frente al diagnóstico de una primoinfección materna en el primer trimestre del embarazo se recomienda el tratamiento con VACV hasta la amniocentesis, para evitar la infección fetal. Se debe monitorizar la función renal cada semana y recomendar la hidratación. Con esta evidencia, la necesidad de incorporar el cribado universal en el primer trimestre de gestación debería ser considerada en nuestro país.

\section{Tratamiento del feto con infección por CMV comprobada}

\section{INMUNIZACIÓN PASIVA CON IG HIPERINMUNE ESPECÍFICA DE CMV}

Los datos de tratamiento con Ig-CMV del feto con infección comprobada corresponden a series de $\operatorname{casos}^{79,80}$, sin que se hayan realizado estudios aleatorizados controlados. En el clásico estudio de Nigro et al. ${ }^{65}$ se utilizó tratamiento en fetos infectados, determinados por amniocentesis positiva (15 binomios), con Ig-CMV en dosis de $200 \mathrm{U} / \mathrm{kg}$ por vía intravenosa a las madres, y adicionalmente, en caso de alteraciones fetales demostradas y persistentes, se agregaron $400 \mathrm{U} / \mathrm{kg}$ intracordón umbilical o intramniótico (calculado por peso fetal), demostrando infección en el RN en el $3,2 \%$ en quienes recibieron la terapia frente al $50 \%$ en quienes no la recibieron. Este estudio no tuvo seguimiento a largo plazo. Posteriormente, los mismos autores $^{81}$, en una serie de cinco casos con fetos con ventriculomegalia, tres recibieron Ig-CMV (mismo protocolo que en 2005) y fueron asintomáticos al nacer, a los 4 y 7 años, y los dos no tratados nacieron con grave compromiso del SNC. En el año 2012 se publicaron tres estudios. Uno de ellos ${ }^{82}$ describió la utilización de Ig-CMV como tratamiento en tres binomios, resultando todos los pacientes asintomáticos al nacer y a los 18-36 meses de evaluación posterior. Otro estudio ${ }^{83}$, luego de ofrecer una dosis $200 \mathrm{U} / \mathrm{kg}$ de Ig-CMV, evaluó los resultados hasta el año de vida (secuelas neurológicas, auditivas, coriorretinitis, enterocolitis necrosante, daño hepático crónico) y concluyó que el $13 \%$ de los niños que recibieron tratamiento presentaron alteraciones, frente al $43 \%$ de los que no recibieron terapia. Finalmente, Nigro et al. ${ }^{70}$ realizaron un estudio retrospectivo con evaluación de desenlaces neurológicos al año de vida y concluyeron que, para todos los niños con $\mathrm{CMVc}$, el único factor de riesgo para tener afectación neurológica era que la madre no hubiese recibido $\lg (p=0,001)$.

Este panel concluye que, considerando los datos expuestos, que están basados solo en series de casos, con poca uniformidad en los esquemas y con evaluación a largo plazo a diferentes edades, mientras no existan estudios aleatorizados, y teniendo en cuenta el costo de la terapia, se debería evaluar, caso a caso, la utilización como terapia de rescate en fetos afectados 
y solo en el contexto de estudios de investigación con consejería y consentimiento.

\section{Antivirales}

El GCV y el VGCV se han utilizado para el tratamiento de la infección fetal en los tres trimestres de la gestación, sin que se haya demostrado toxicidad en los $\mathrm{RN}$, pero la experiencia es muy limitada ${ }^{84}$. Existen escasos reportes de su uso en el embarazo, en el contexto de mujeres gestantes con inmunosupresión secundaria a trasplante renal o infección por el virus de la inmunodeficiencia humana $(\mathrm{VIH})$ con reactivación o reinfección por $\mathrm{CMV}^{85,86}$. Seidel et al. ${ }^{84}$ reportaron tres pacientes con detección de infección fetal a las que se administró VGCV, $900 \mathrm{mg}$ al día, en el tercer trimestre. En los tres casos, al momento del nacimiento la viremia y la viruria resultaron negativas, explicado por el efecto del tratamiento antiviral, pero se tornaron positivas a las 2 semanas de vida. Aún faltan estudios y seguimiento a largo plazo de pacientes tratados in utero con GCV/VGCV durante el embarazo.

El primer estudio de uso de VACV para tratamiento in utero fue publicado por Jacquemard et al. ${ }^{74}$, en una experiencia piloto, en la que trataron a 20 madres con primoinfección e infección fetal demostrada con VACV desde las 28 semanas de gestación (22-34 semanas) durante 7 semanas (1 a 12 semanas), con un adecuado perfil de seguridad. El objetivo de este estudio fue evaluar la farmacocinética del VACV durante el embarazo y el impacto en la carga viral fetal. Observaron una disminución significativa de la carga viral, que se asoció a un mejor pronóstico. Diez RN nacieron asintomáticos, dos con hipoacusia sensorioneural grave unilateral y otro con microcefalia y sordera bilateral profunda, pero junto con otro diagnóstico concomitante. En los siete casos restantes hubo interrupción del embarazo debido al diagnóstico fetal ${ }^{74}$.

Posteriormente, un estudio multicéntrico no aleatorizado realizado por Leruez-Ville y Ville ${ }^{87}$, en mujeres embarazadas con infección fetal demostrada en el segundo trimestre, utilizando la misma dosis de VACV que Jacquemard et al..$^{74}$ ( $8 \mathrm{~g}$ al día, $2 \mathrm{~g}$ cada $6 \mathrm{~h}$ ), desde el momento del diagnóstico de la infección fetal hasta el parto, mostró un porcentaje de RN asintomáticos mayor que en el grupo control histórico de mujeres embarazadas no tratadas: 82\% (IC95\%: 0,67-0,88) frente a $42 \%$ (IC95\%: 0,29-0,57). Este estudio solo incluyó fetos con alteraciones cerebrales no profundas, que en teoría se podrían beneficiar del tratamiento.
La experiencia de uso del VACV para el tratamiento fetal es cada vez mayor en los centros de medicina materno-fetal de Europa. De la Calle et al. ${ }^{61}$, en España, describen por primera vez el uso de tratamiento combinado con VACV asociado a Ig-CMV en una a tres dosis en 15 mujeres, pero dado el número reducido de pacientes y la falta de grupo control, no es posible sacar conclusiones sobre el impacto en los $\mathrm{RN}$ y las secuelas a largo plazo.

No existen a la fecha publicaciones de estudios aleatorizados, controlados, que evalúen este escenario de tratamiento de infección fetal demostrada, pero podría considerarse desde el diagnóstico de infección fetal hasta el parto.

El letermovir es un inhibidor de la enzima terminasa viral, que actúa en las fases finales de la replicación,

\section{Recomendación \# 3: tratamiento de la mujer embarazada con infección por CMV}

- Tratamiento para prevención de la infección fetal:

- VACV: se recomienda el tratamiento con VACV en caso de primoinfección demostrada en el primer trimestre del embarazo (recomendación fuerte, alta calidad de evidencia).

Dosis: $8 \mathrm{~g}$ al día (2 g cada $6 \mathrm{~h}$ ) hasta la amniocentesis.

Se debe monitorizar la función renal semanalmente y recomendar la hidratación.

- Ig-CMV: considerar el uso de Ig-CMV para la prevención de infección fetal en caso de primoinfección en el primer trimestre (recomendación débil, moderada calidad de evidencia).

Dosis: $200 \mathrm{U} / \mathrm{kg}$ cada 2 semanas durante la primera mitad del embarazo y hasta la amniocentesis.

- Tratamiento de la infección fetal:

- VACV: considerar el tratamiento con VACV en caso de infección fetal demostrada, sin lesiones profundas en las neuroimágenes fetales, independientemente de la edad gestacional al diagnóstico (recomendación débil, baja calidad de evidencia). Dosis: $8 \mathrm{~g}$ al día (2 g cada 6 h) hasta el parto. Se debe monitorizar la función renal semanalmente y recomendar la hidratación.

- Ig-CMV: no se recomienda el uso de Ig-CMV para el tratamiento de la infección fetal demostrada, salvo en el contexto de estudios de investigación o uso compasivo (recomendación débil, muy baja calidad de evidencia). 
y que ha sido licenciado recientemente para profilaxis en pacientes receptores de trasplante renal ${ }^{88}$. Existe un estudio en desarrollo (CYMEVAL III, Francia), aleatorizado, doble ciego, controlado, en el que se compara VACV (8 g al día) como tratamiento estándar con letermovir ( $240 \mathrm{mg}$ al día) en mujeres gestantes con infección por CMV en el primer trimestre e infección fetal (PCR-CMV en líquido amniótico positivo). El objetivo primario es evaluar la proporción de RN asintomáticos y con PCR-CMV en sangre negativo al nacer. Aún no hay datos publicados al respecto (https://www.clinicaltrialsregister.eu/ctr-search/trial/2020-002924-35/FR).

\section{Prevención de la infección por CMV en la mujer embarazada}

\section{Higiene y educación}

La prevención primaria consiste en evitar la adquisición de la infección por CMV en las mujeres gestantes seronegativas. La principal forma de evitar su contagio es educar a la población de riesgo sobre el CMV, sus consecuencias en el feto y el RN, y fomentar las medidas de prevención. El pilar en la prevención, al igual que en otras enfermedades infectocontagiosas, es la higiene de manos. Estas medidas disminuyen el riesgo de la infección por CMV en el embarazo, pero no la eliminan ${ }^{89}$.

El riesgo de primoinfección aumenta en las mujeres jóvenes y en contacto con otros niños, sobre todo si asisten a sala cuna o jardín infantil. En una experiencia francesa, las mujeres que eran seronegativas en su primer embarazo y se embarazaron nuevamente en los siguientes 2 años tenían casi 20 veces más riesgo de primoinfección, y 5 veces más riesgo de secuelas de dicha infección en su segundo embarazo que la población general ${ }^{90}$. A su vez, se ha descrito un riesgo de seroconversión anual del $24 \%$ en madres de niños pequeños con excreción viral activa, del $8,5 \%$ en trabajadoras de salas cunas o jardines infantiles, del 2,3\% en trabajadoras de la salud y del $2,3 \%$ en mujeres embarazadas en general, por lo que la educación sobre la forma de adquisición del CMV es fundamental $^{91}$ (Tabla 3).

\section{Vacunas}

Actualmente hay cuatro tipos de vacunas frente al CMV en desarrollo: vacunas vivas atenuadas, inactivadas, vacunas basadas en vectores virales y vacunas de ácidos nucleicos (ADN/ARN). A la fecha, hay tres
Tabla 3. Prevención de infección por CMV en el embarazo

1 Educar a las mujeres embarazadas sobre la infección por CMV y sus consecuencias

2 Lavado de manos frecuente, sobre todo después de tener contacto con saliva, orina o deposiciones de un lactante

3 Evite tener contacto con saliva de lactantes o niños pequeños (ej.besos en la boca, chupete, cepillo de dientes)

4 No comparta comida, bebida o cubiertos con lactantes o niños pequeños

5 Limpie juguetes, mudadores o superficies que estén en contacto con orina o saliva de lactantes o niños pequeños

6 En caso de ser personal de salud, evite el contacto con fluidos corporales de lactantes o niños pequeños. Se deben adoptar precauciones estándar en la atención.

candidatas con ensayos clínicos en fases iniciales en seres humanos para infección congénita por $\mathrm{CMV}^{92,93}$. La primera es la vacuna de partículas virales envueltas (eVLP: virus like particle vaccine), que expresa el dominio extracelular de la glucoproteína de superficie B (gB) y estimula una amplia gama de anticuerpos neutralizantes. Se ha completado un ensayo clínico de fase I con gB/eVLP, pero los resultados aún no están publicados $^{40}$. La segunda es una vacuna de virus vivos (AD169) atenuados, modificados para mejorar la inmunogenicidad, pero limitando su replicación. La inmunogenicidad se basa en la restauración de genes para las proteínas del CMV que forman el complejo pentamérico de la envoltura viral (gH/gL/pUL128/pUL130/pUL131) ${ }^{40}$. Un ensayo clínico de fase I con esta vacuna en adultos sanos seronegativos demostró una persistencia de títulos de anticuerpos neutralizantes similar a la de los sujetos no vacunados con infección previa ${ }^{40}$. La tercera es una vacuna de ARN mensajero encapsulada en una nanopartícula lipídica con información para sintetizar gB y el complejo pentamérico (ARNm-1647) ${ }^{40}$. Actualmente se encuentran en programación estudios de fase 3 en mujeres seronegativas entre 16 y 40 años de edad (clinicaltrials.gov: NCT03382405 y NCT04232280).

La principal dificultad para generar una vacuna eficaz contra el CMV son las características propias de la infección por un virus latente (como otros virus de la familia Herpesvirus), pues la vacuna debe ser capaz de controlar tanto la primoinfección como los episodios de reactivación o reinfección ${ }^{94}$. 


\section{Cribado serológico en la mujer embarazada}

El cribado serológico de CMV en la mujer embarazada fue controversial debido a la dificultad en el diagnóstico materno y a la ausencia de una opción terapéutica segura y efectiva hasta hace algunos años. Sin embargo, los principales puntos que hacen replantearse el cribado serológico en el embarazo son:

- Se conoce que los RN con enfermedad grave y secuelas importantes corresponden exclusivamente a infección periconcepcional o del primer trimestre de gestación: el 19-28\% de los niños infectados en este período, comparados con el $0,9 \%$ y el $0,4 \%$ de riesgo cuando la infección fetal se produce en el segundo 0 el tercer trimestre de gestación, respectivamente ${ }^{16}$.

- Existe mundialmente la factibilidad de diagnóstico para detectar mujeres embarazadas que estén teniendo una infección en este período de la gestación, mediante cribado con serología, avidez y, eventualmente, PCR-CMV en casos seleccionados. La combinación de $\lg \mathrm{M}$ e $\lg \mathrm{G}$ positivas con un índice de avidez bajo es indicativa de una infección de menos de 3 meses de antigüedad, con más del $90 \%$ de sensibilidad y especificidad ${ }^{95}$.

- Se dispone de estudios aleatorizados que muestran una reducción significativa $(71 \%$, OR: 0,29) del riesgo de infección fetal con el uso de antivirales cuando se detecta a una mujer con infección en el primer trimestre de gestación ${ }^{78}$. Esto permite ofrecer una opción terapéutica a una madre con infección por CMV en el período de mayor riesgo de transmisión de la infección al feto y evitar morbimortalidad en el RN.

- Además, la pesquisa en la madre permite aumentar la detección de RN con infección congénita, incluidos los asintomáticos al nacer, que igualmente requerirán seguimiento posnatal por riesgo de manifestaciones más tardías de la enfermedad.

A la luz de los últimos estudios publicados, este panel estima que hay datos científicos suficientes para proponer el cribado a toda mujer embarazada en Chile, si bien se reconocen limitaciones y dificultades en la realidad nacional, tales como la imposibilidad de realizar el test de avidez (no disponible) y el tiempo limitado para lograr un adecuado diagnóstico e iniciar un tratamiento efectivo en la madre. Por último, reconocemos la falta de datos actualizados, en especial de estudios de prevalencia, y consideramos urgente avanzar en ello para poder determinar el porcentaje de embarazadas susceptibles de adquirir una infección primaria durante la gestación, considerando además los cambios poblacionales ocurridos en la última década.

\section{Infección por CMV en el recién nacido}

El $90 \%$ de los RN infectados por CMV durante el embarazo nacen asintomáticos. Por ello, es fundamental tener un alto índice de sospecha de la infección congénita y solicitar el estudio diagnóstico antes de los 21 días de vida ${ }^{3,96}$ (Tabla 1). La detección posterior a este plazo sugiere que la infección puede haberse adquirido en forma posnatal (por secreciones vaginales, leche materna y otras vías), y no es posible diferenciarla de una infección congénita.

\section{Sospecha clínica en el recién nacido}

- RN con antecedentes de infección materna conocida durante el embarazo (primoinfección o infección no primaria) o frente a hallazgos en la ecografía prenatal compatibles con infección fetal (Tabla 2), o con diagnóstico de infección fetal (RCP-CMV positiva en líquido amniótico) en los cuales se debe confirmar la infección al nacer.

- RN que presenta signos y síntomas compatibles con infección congénita (Tabla 4). Si bien el CMV es una de las causas más frecuentes de infección congénita (SCORTCH), se debe hacer el diagnóstico diferencial con otras patologías ${ }^{44,45}$. Considerar el cribado de VIH, sífilis, enfermedad de Chagas y hepatitis B en el control del embarazo, indagar sobre antecedentes epidemiológicos maternos (consumo de carne parcialmente cocida, contacto con animales, viajes), y comprobar su estado vacunal, y así orientar el estudio de otras infecciones congénitas.

- RN PEG. La infección por CMV es una causa conocida de retardo en el crecimiento intrauterino secundario a la insuficiencia placentaria generada por la infección de las células trofoblásticas ${ }^{97,98}$ (v. apartado «Fisiopatología de la infección en el feto»). El estudio de CMV en un RN PEG (menor que el percentil 10) sin otro síntoma es controversial ${ }^{44,96,99}$; sin embargo, en el contexto de una búsqueda activa o un cribado selectivo de CMV en RN, Lorenzoni et al. ${ }^{100}$ estudiaron 504 RN prematuros o PEG graves (menor que el percentil 3) y encontraron un 3,7\% de RN positivos para CMV. A su vez, en una experiencia nacional de cribado de CMV en RN hospitalizados se observó que el 3,3\% de los PEG graves estudiados presentaron una infección congénita por CMV, sin hallar otra causa atribuible al bajo peso en un $40 \%$ de ellos ${ }^{101}$. 
Tabla 4. Definiciones operacionales, hallazgos clínicos y de laboratorio más frecuentes en RN con CMVc

\begin{tabular}{|c|c|c|}
\hline Signos clínicos & Definición/Comentar & $\begin{array}{l}\text { Frecuencia de } \\
\text { presentación }\end{array}$ \\
\hline $\begin{array}{l}\text { Petequias o púrpura } \\
\text { Exantema tipo "blueberry muffin" }\end{array}$ & $\begin{array}{l}\text { Al nacer o en las primeras horas de vida, pueden persistir por varias semanas } \\
\text { Secundario a focos de eritropoyesis extramedular intradérmica }\end{array}$ & $50-75 \%$ \\
\hline Ictericia & Puede estar presente desde el primer día de vida & $40-70 \%$ \\
\hline Hepato-esplenomegalia & Buscar dirigidamente al examen físico & $60 \%$ \\
\hline Pequeño para la edad gestacional & Peso de nacimiento menor al p10 & $40-50 \%$ \\
\hline Microcefalia & Perímetro cefálico $<2$ DS para la EG & $21-50 \%$ \\
\hline Signos neurológicos & $\begin{array}{l}\text { Letargia e hipotonía } \\
\text { Crisis convulsivas } \\
\text { Reflejo de succión pobre }\end{array}$ & $\begin{array}{c}30 \% \\
7-20 \% \\
5-10 \%\end{array}$ \\
\hline Coriorretinitis & Evaluado dirigidamente por oftalmólogo & $10-20 \%$ \\
\hline $\begin{array}{l}\text { Hallazgos de laboratorio } \\
\text { Aumento de transaminasas } \\
\text { Hiperbilirrubinemia conjugada } \\
\text { Hemograma }\end{array}$ & $\begin{array}{l}\mathrm{GPT}>80 \mathrm{UI} / \mathrm{L} \\
\text { Bilirrubinemia directa }>2 \mathrm{mg} / \mathrm{dl} \\
\text { Trombocitopenia: recuento plaquetas }<100.000 / \mathrm{mm}^{3} \\
\text { Anemia: hematocrito }<40 \% 0-7 \text { días, }<35 \% \text { entre los } 8-14 \text { días } y<30 \% \text { entre } \\
\text { los } 15 \text { a } 28 \text { días de vida. } \\
\text { Neutropenia: RAN }<1500 \text { células } / \mathrm{mm}^{3} \\
\text { Neutropenia profunda: RAN }<500 \text { células } / \mu \mathrm{L} \\
\text { Proteinorraquia }>120 \mathrm{~g} / \mathrm{dL} \\
\text { Presencia de una RPC-CMV positiva en LCR }\end{array}$ & $\begin{array}{c}83 \% \\
81 \% \\
70 \% \\
5-10 \%\end{array}$ \\
\hline
\end{tabular}

CMV: citomegalovirus; RPC: reacción de polimerasa en cadena; LCR: líquido cefalorraquídeo, RAN: recuento absoluto de neutrófilos Adaptado de: Boppana SB y cols, Clin Infect Dis. 2013;57 (Suppl 4):S178-81. Boppana SB y cols. Pediatr Infect Dis J 1992; 11:93-9.*

Recomendamos la búsqueda de CMV en todo RN PEG grave independientemente de la causa, y en los RN PEG no graves siempre y cuando se asocie a alguna alteración clínica o de laboratorio (v. apartado "Cribado en el recién nacido»).

- Todo RN hijo de madre con infección por VIH, independientemente de la etapa de la infección, la carga viral, el recuento de CD4 y la terapia antirretroviral ${ }^{102}$. Las madres infectadas con $\mathrm{VIH}$ tienen 2,9 a 3,5 veces más probabilidades de transmitir el CMV in utero a sus hijos ${ }^{103,104}$, a través de primoinfección o por infección no primaria materna ${ }^{105}$. La prevalencia de CMVc varía entre el $4 \%$ y el $26 \%$ en los $\mathrm{RN}$ con infección por VIH y entre el $1,2 \%$ y el $5 \%$ en aquellos expuestos al VIH pero no infectados ${ }^{103,106,107}$. Si bien la incidencia ha ido disminuyendo en los últimos años gracias a la terapia antirretroviral efectiva ${ }^{108,109}$, el principal factor de riesgo de transmisión es el recuento de linfocitos T-CD4 maternos $<200$ céls/ml durante el embarazo (OR: 2.9; IC95\%: 1.2-7.3; $p=0,02)^{107}$.

- Todo RN que «no pasa» o «refiere» el cribado auditivo universal. La infección por CMV es la principal causa de hipoacusia sensorioneural congénita no genética en la infancia. Aproximadamente el $20 \%$ de las
Recomendación \# 4: indicaciones de estudio diagnóstico de CMV congénito

- RN con antecedentes de infección materna conocida durante el embarazo (primoinfección o infección no primaria) o con hallazgos en la ecografía prenatal compatibles con infección fetal (Tabla 2) (recomendación fuerte, alta calidad de evidencia).

- Diagnóstico de infección fetal confirmada por PCR-CMV en líquido amniótico (recomendación fuerte, alta calidad de evidencia).

- RN que presenten signos y síntomas compatibles con infección congénita (Tabla 4) (recomendación fuerte, alta calidad de evidencia).

- RN hijo de madre con infección por VIH (recomendación fuerte, alta calidad de evidencia).

- RN que «no pasa» o «refiere» el cribado auditivo (recomendación fuerte, alta calidad de evidencia).

- RN PEG grave (< p3) independientemente de la causa o PEG no grave (p3-10) asociado a otro hallazgo clínico o de laboratorio (recomendación fuerte, baja calidad de evidencia).

hipoacusias sensorioneurales al nacer y el $25 \%$ de las que se diagnostican en la edad preescolar son 
atribuibles a esta infección ${ }^{5}$. Se debe recordar que el cribado auditivo solo detecta un $20 \%$ a un $60 \%$ de las hipoacusias sensorioneurales asociadas a CMVc, debido a que el resto pueden ser de aparición tardía $(43 \%)$ (v. apartado «Cribado en el recién nacido") ${ }^{110-112}$.

Además, se estima que existiría una mayor frecuencia de CMVc en RN que «refieren» o «no pasan» el estudio auditivo neonatal, fluctuando entre el $1 \%$ y el $7 \%{ }^{101,113,114}$, por lo que recomendamos solicitar PCRCMV en orina o saliva ante el primer estudio auditivo que «no pasa» si es que no es posible repetirlo antes de los 21 días, para no perder la posibilidad de realizar el diagnóstico de CMVc.

\section{Clasificación de la infección por CMV congénita}

Existe controversia sobre la clasificación clínica de un RN con CMVc. La definición de infección sintomática varía entre los consensos publicados en el año $2017^{2,96}$, siendo a la fecha «aquel RN con signos y síntomas presentes al examen físico", tales como PEG grave, microcefalia, petequias o hepatoesplenomegalia. La principal diferencia entre ellos es la incorporación de la hipoacusia sensorioneural aislada como parte del compromiso del SNC en el Consenso Europeo, que sugiere realizar estudios adicionales para evaluar otros órganos ${ }^{96}$, a diferencia del Consenso Americano, que considera como asintomático al RN con hipoacusia sensorioneural unilateral ${ }^{2}$.

Los RN con síntomas graves incluyen aquellos con compromiso del SNC, como microcefalia, alteraciones de las neuroimágenes (v. apartado «Estudio por imágenes"), pleocitosis o presencia de ADN del CMV en líquido cefalorraquídeo (LCR), coriorretinitis e hipoacusia sensorioneural unilateral o bilateral. También se consideran graves aquellos con compromiso específico de algún órgano grave o multiorgánico (sepsis viral, miocarditis, hepatitis grave, hepatoesplenomegalia, neumonía, enterocolitis, trombocitopenia refractaria y profunda, síndrome hemofagocítico), siendo los casos moderados más heterogéneos en su definición. Los casos leves (área gris) habitualmente son pesquisados cuando se realiza una búsqueda activa por los antecedentes maternos o ecográficos, en cribado neonatal o en el contexto de estudios de investigación, y son aquellos con una evaluación clínica normal, pero con alguna alteración de laboratorio o de imágenes, como aumento de las transaminasas, hepatomegalia leve o trombocitopenia leve de resolución espontánea (antes de 2 semanas). Los
RN PEG graves sin otra alteración podrían considerarse también dentro de esta clasificación.

Por otro lado, un estudio retrospectivo realizado por Ronchi et al. ${ }^{115}$, en el que se evaluaron $34 \mathrm{RN}$ con CMVc definidos como asintomáticos, identificados por antecedentes maternos o falla en el cribado auditivo, demostró que el $56 \%$ de ellos tuvieron al menos una alteración en la evaluación oftalmológica, los exámenes de laboratorio o las neuroimágenes, siendo reclasificados como sintomáticos. Por otra parte, BlazquezGamero et al. ${ }^{116}$ describen una cohorte española de RN diagnosticados por antecedentes maternos o sospecha de infección congénita, en la que solo $49 \mathrm{RN}$ de $102(46 \%)$ presentaban únicamente hallazgos en el examen físico, pero luego de una evaluación completa 77 (72\%) fueron clasificados como sintomáticos. Un $45 \%$ presentaron alguna alteración en los exámenes de laboratorio, siendo la trombocitopenia y el aumento de las transaminasas las más frecuentes; el $42 \%$ no pasaron el estudio auditivo y a $5 \%$ se les pesquisó coriorretinitis en la evaluación oftalmológica. A su vez, los mismos autores describen que cerca de un tercio de los $\mathrm{RN}$ con ecografía cerebral normal presentaron algún

\section{Puntos clave \# 3}

Se define CMVc como:

- Sintomático grave:

- Compromiso del SNC: alteración en el examen neurológico, microcefalia, alteraciones de las neuroimágenes compatibles, pleocitosis, proteinorraquia o presencia de ADN del CMV en LCR, coriorretinitis o hipoacusia sensorioneural unilateral o bilateral independientemente de la gravedad.

- Compromiso específico de un órgano grave o multiorgánico: sepsis viral, miocarditis, hepatitis grave, hepatoesplenomegalia, neumonía, enterocolitis, trombocitopenia profunda $\left(<25.000 \mathrm{~mm}^{3}\right)$, síndrome hemofagocítico.

- Sintomático moderado: compromiso moderado o persistente por más de 2 semanas de un órgano específico compatible con infección por CMV.

- Sintomático leve (área gris): compromiso de un órgano aislado y en forma transitoria, como aumento de transaminasas, leve hepatomegalia o trombocitopenia leve de resolución espontánea antes de 2 semanas; o en un PEG grave sin otra alteración.

Este panel sugiere definir un RN como «verdaderamente asintomático" al que, después de una exhaustiva evaluación clínica, oftalmológica y audiológica, así como de exámenes de laboratorio e imágenes, no presenta hallazgos compatibles con CMVc. 
hallazgo compatible en la RM, aumentando la importancia de la evaluación con este método en los RN con $\mathrm{CMVC}^{117}$ (v. apartado «Estudio por imágenes»).

La definición habitual ${ }^{118}$, basada en aspectos netamente clínicos, tiene limitaciones y puede llevar a la omisión de un porcentaje no menor de casos. Realizar una evaluación completa con estudios de laboratorio e imágenes permitiría reclasificar como sintomático ${ }^{115} a$ un RN catalogado como asintomático, y evitar perder la oportunidad de tratar a un RN con CMVc, con todas las potenciales secuelas que conlleva en múltiples áreas del desarrollo ${ }^{119}$.

\section{Métodos de diagnóstico de la infección por CMV congénita}

Tradicionalmente, el método diagnóstico de referencia era el cultivo viral en orina dentro de los primeros 21 días de vida ${ }^{120,121}$. Sin embargo, la PCR para la detección de ADN del CMV se ha transformado en el método de referencia actual, con una sensibilidad y una especificidad superiores que las de los cultivos virales tradicionales y acelerados (shell vial), en muestras tanto de orina como de saliva, que concentran una alta carga viral en el niño con infección congénita ${ }^{120-124}$. Los escasos reportes de PCR-CMV falsamente negativas pueden estar relacionados con la presencia de inhibidores de la técnica; sin embargo, con los actuales controles internos esta situación es casi inexistente ${ }^{125}$.

La PCR-CMV en hisopado de saliva es una técnica sencilla, para la que la muestra se obtiene de manera inmediata, no invasiva y fácil, y además permite analizar la muestra con saliva fresca o seca, con una duración de esta última de hasta 7 días ${ }^{126}$. Con la muestra de saliva se mantienen unas altas sensibilidad (97,4$100 \%$ ) y especificidad $(99,9 \%)^{126}$, pero se requiere la confirmación con una muestra de orina, dado el riesgo de falsos positivos secundarios a la contaminación por CMV excretado en la leche materna ${ }^{116,126}$. Para evitar falsos positivos, la muestra debe tomarse más de 1 hora después de la última alimentación, con aseo previo de la cavidad oral, lo cual involucra un adecuado entrenamiento en la técnica al personal de salud a cargo $^{127,128 .}$.

Las muestras (orina, saliva, sangre y LCR) para diagnóstico por PCR-CMV pueden ser almacenadas a $4{ }^{\circ} \mathrm{C}$ durante 48 horas y a -20 a $-70{ }^{\circ} \mathrm{C}$ durante al menos 1 mes, lo que permite derivar la muestra para su estudio en centros donde no se dispone de la técnica.

La serología (IgM e IgG) en el RN no está recomendada debido a que, si bien la presencia de IgM positiva podría indicar una infección aguda ${ }^{129}$, puede ser falsamente negativa en cerca del $50 \%$ de los RN infectados. Su positividad debe confirmarse con técnicas moleculares y considerar que una IgM negativa no descarta el diagnóstico. Por otra parte, la presencia de $\lg G$ es de poca utilidad, pues puede reflejar el paso de anticuerpos maternos a través de la placenta. Por lo tanto, la serología, aunque no es de las herramientas diagnósticas iniciales, puede ser un recurso en ausencia de los exámenes virológicos arriba detallados ${ }^{130}$.

Cuando el diagnóstico de CMVc ocurre después de la tercera semana de vida, no es posible diferenciar en forma categórica una infección congénita de una infección posnatal. En esta situación, el diagnóstico retrospectivo con detección de ADN del CMV por PCR en sangre almacenada en papel filtro prometió ser un buen método de detección ${ }^{131}$; sin embargo, Boppana et al. ${ }^{132}$ demostraron una sensibilidad menor del 30\% comparándola con cultivos de muestras de saliva. Una nueva técnica de extracción y PCR-CMV para la muestra de papel filtro, descrita por Dollard et al. ${ }^{133}$, alcanza una sensibilidad del $80 \%$, por lo que ha empezado a tener un mayor valor en el diagnóstico retrospectivo de la infección neonatal. Sus principales limitaciones son que los RN con CMVc pueden no tener viremias detectables al nacer y que no está ampliamente disponible en los laboratorios de nuestro país ${ }^{134,135}$.

En la práctica diaria, en ocasiones es complejo tener el diagnóstico antes de los 21 días de vida. Se recomienda, en tales casos, discutir el caso con el infectólogo pediátrico, con el objetivo de realizar un análisis de los signos y síntomas presentes en cada paciente e indicar el tratamiento a la mayor brevedad, si corresponde.

\section{Recomendación \# 5: técnicas para el diagnósti- co de CMV congénito}

- El diagnóstico de CMVc se realiza mediante PCRCMV en orina antes de los 21 días de vida (método de referencia actualmente) (recomendación fuerte, alta calidad de evidencia).

- Las muestras positivas en saliva deben ser confirmadas con una PCR-CMV en orina para detectar falsos positivos por contaminación de la muestra (recomendación fuerte, alta calidad de evidencia).

- Podrían utilizarse a futuro técnicas de detección de CMV en papel filtro para el diagnóstico retrospectivo de infección congénita, cuando esta se sospecha después de la tercera semana de vida (recomendación débil, baja calidad de evidencia). 


\section{Evaluación clínica y de laboratorio del recién nacido con infección congénita por CMV confirmada}

\section{EVALUACIÓN CLÍNICA}

La exploración física debe ser completa, con principal énfasis en los hallazgos clínicos sugerentes: piel y mucosas (ictericia, petequias), visceromegalia 0 alteraciones oculares $^{32}$. El examen neurológico debe ser realizado por un neurólogo infantil o por un médico con experiencia en examen neurológico neonatal (para pesquisar hallazgos sutiles como letargia, hipotonía o hipertonía). Además, se debe hacer una evaluación antropométrica con peso, talla y circunferencia craneal, y clasificar al RN en adecuado para la edad gestacional, PEG o grande para la edad gestacional ${ }^{136,137}$ (Tabla 4).

\section{EVALUACIÓN DE LABORATORIO}

Se sugiere realizar un estudio exhaustivo de todos los RN con CMVc para objetivar el compromiso de órgano específico y categorizar adecuadamente en sintomático 0 «verdadero» asintomático. Esto permitirá un correcto manejo terapéutico y el seguimiento a corto y largo plazo.

Los exámenes y las evaluaciones recomendados para el estudio son los siguientes:

- Hemograma completo con recuento plaquetario.

- Pruebas de función hepática: aspartato aminotransferasa (AST), alanina aminotransferasa (ALT), gammaglutamil transferasa (GGT) y bilirrubinemia total y directa.

- Pruebas de función renal: creatininemia, nitrógeno ureico en sangre y orina completa.

- Detección de ADN del CMV cuantitativa en sangre mediante PCR: la carga viral de CMV al nacer depende del momento de la infección intrauterina y del estado inmunitario del paciente. Un estudio multicéntrico, realizado en $73 \mathrm{RN}$ con $\mathrm{CMVc}$ sintomático, señala que la mayor carga viral al diagnóstico se correlaciona con la presencia de trombocitopenia, aumento de transaminasas y compromiso del SNC, sin existir aún un punto de corte determinado y con escaso valor predictor en relación al pronóstico neurológico y auditivo a largo plazo ${ }^{138}$. Si bien aún no existe un valor de corte de carga viral que permita diferenciar entre RN sintomáticos y asintomáticos, se ha observado que un RN con viremia > 10.000 co$\mathrm{pias} / \mathrm{ml}(\log 4)$ al diagnóstico tiene una probabilidad de presentar una enfermedad moderada-grave cercana al $75 \%$, y por ende requiere tratamiento antiviral $^{139}$. Por otra parte, hay que recordar que una carga viral en sangre negativa no descarta el diagnóstico de $\mathrm{CMVC}^{135}$, ya que entre el $10 \%$ y el $20 \%$ de los RN no tienen viremia detectable al momento de la evaluación ${ }^{134,135}$. La PCR-CMV cuantitativa se realiza en sangre total (tubo con anticoagulante EDTA).

- Estudio de LCR: la pesquisa de ADN del CMV en LCR se ha relacionado con alteraciones del neurodesarrollo en RN con CMVc sintomáticos, y se ha considerado como un marcador de compromiso del SNC, a pesar de que su presencia es poco frecuente ${ }^{140}$. Oullette et al. ${ }^{141}$ analizaron la positividad de la PCR-CMV en LCR de 22 RN sintomáticos, "clínicamente aparentes», y no hubo diferencias en alteraciones de laboratorio, neuroimágenes ni hipoacusia sensorioneural, por lo que plantean que la indicación de punción lumbar en el RN con CMVc es aún controversial. Por otra parte, Goycochea-Valdivia et al. ${ }^{142}$ realizaron un estudio retrospectivo, utilizando la base de datos española de CMVc. De un total de $136 \mathrm{RN}$ evaluados con punción lumbar y búsqueda de ADN del CMV en LCR, 21 (15,4\%) presentaron LCR positivo, $17(22 \%)$ de ellos del grupo sintomático y $4(6,8 \%)$ pacientes clasificados como asintomáticos. No hubo diferencias significativas en presencia de microcefalia, hallazgos en la neuroimágenes ni pronóstico neurológico y auditivo a los 6 meses; sin embargo, los cuatro pacientes asintomáticos recibieron tratamiento antiviral y se siguieron a corto plazo. Recientemente se analizaron los datos de $168 \mathrm{RN}$ de un centro donde se realiza punción lumbar sistemáticamente en la evaluación de los niños con CMVc. De ellos, 23 (13,7\%) tuvieron PCR-CMV en LCR positiva. Todos fueron clasificados como sintomáticos al nacer y su pesquisa se asoció a un mayor compromiso del SNC, incluyendo alteraciones en la RM (OR: 7,19; IC95\%: 1,67-30,97; $p=0,008$ ) e hipoacusia sensorioneural profunda (OR: 7,18; IC95\%: 1,75-29,3; $p=0,006)$. La detección de ADN del CMV en LCR confirma el compromiso del SNC, si bien un resultado negativo no permite descartar el diagnóstico $^{143}$. Un resultado positivo se considera como un CMVc sintomático que requiere tratamiento antiviral. Este panel recomienda realizar el estudio de LCR en todo $\mathrm{RN}$ con $\mathrm{CMV}$, o en caso de que no se disponga de una evaluación exhaustiva del SNC que incluya RM, salvo que sea «evidentemente sintomático». 


\section{ESTUDIO POR IMÁGENES}

Los estudios de neuroimagen son un importante marcador pronóstico en la infección por CMV, por lo que son un complemento fundamental en la evaluación del RN.

\section{Ecografía cerebral}

La ecografía cerebral sigue siendo el estudio diagnóstico de primera línea para RN con CMVc, por ser de fácil acceso y alta sensibilidad para detectar quistes germinolíticos $(26 \%)$, calcificaciones periventriculares $(23 \%)$ y ventriculomegalia $(6,5 \%)$, tríada que está presente en casi un tercio de estos pacientes ${ }^{144}$. Otras alteraciones menos frecuentes son hidrocefalia, adhesiones ventriculares y quistes subependimarios o caudotalámicos. Una de las alteraciones encontrada con frecuencia en estos pacientes es la vasculopatía lenticuloestriada, que corresponde a un aumento de la ecogenicidad de los vasos lenticuloestriados, habitualmente inaparentes. Por sí sola, no se considera un hallazgo compatible con infección por $\mathrm{CMVc}$, ya que está presente en el $0,4 \%$ al $5,8 \%$ de los $\mathrm{RN}$ de término sanos $^{96}$ y hasta en el $15 \%$ de las ecografías de los prematuros ${ }^{145}$. Tiene relación con fenómenos de hipoxia/isquemia expresada en un territorio vascular más vulnerable, y no se ha correlacionado con alteraciones en el neurodesarrollo en el seguimiento a 12 meses $^{117}$.

La ecografía tiene limitaciones en la evaluación de la sustancia blanca y en la detección de anormalidades corticales y de la fosa posterior; esto ha llevado al uso de la RM en forma más precoz y sistemática ${ }^{117,146}$.

\section{Resonancia magnética cerebral}

La RM tiene una capacidad limitada para detectar calcificaciones cerebrales; sin embargo, muestra una sensibilidad marcadamente superior que la ecografía y la tomografía computada ${ }^{147}$ en la detección de lesiones de la sustancia blanca, alteraciones de la migración neuronal (10\%) y lesiones parenquimatosas ${ }^{117,148}$.

Los hallazgos más característicos de infección por CMV incluyen anormalidades de la sustancia blanca (42\%), malformaciones del desarrollo cortical (10\%) e hipoplasia cerebelar (2,8\%). Otros hallazgos, como los quistes periventriculares (24\%), las calcificaciones intracraneales $(17,8 \%)$, la dilatación ventricular $(15 \%)$, las adhesiones intraventriculares $(3,7 \%)$ y la microcefalia son alteraciones más frecuentes, pero poco específicas ${ }^{53}$. Las alteraciones altamente

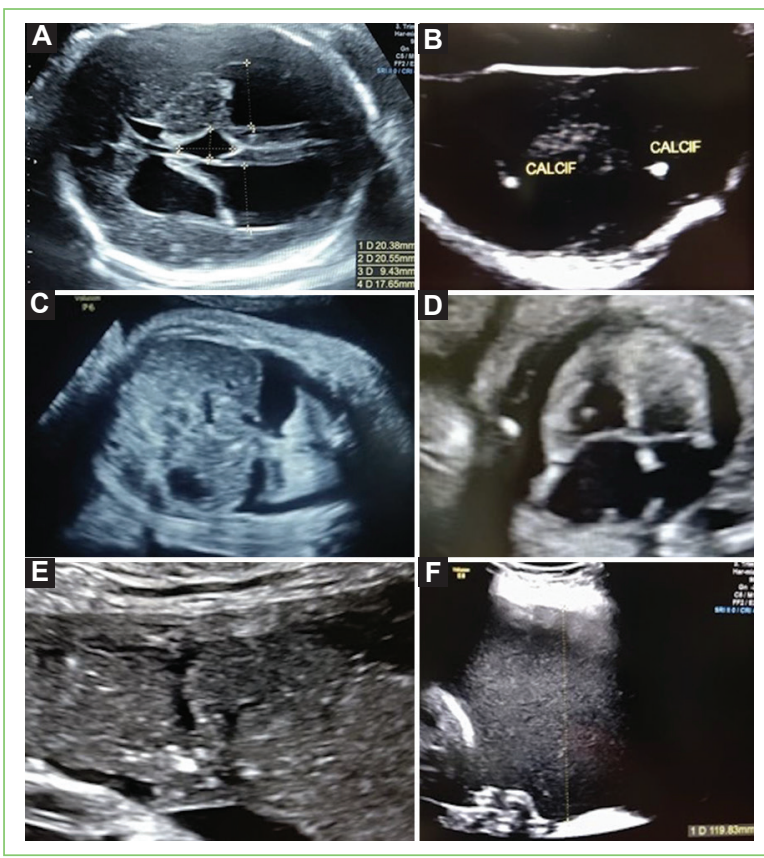

Figura 5. Hallazgos ecográficos fetales sugerentes de CMVc. A: hallazgos intracraneales, B: hidrocefalia. Calcificaciones periventriculares. C: hallazgos extracraneales: Derrame pleural; D: derrame pericardico. Hallazgos en placenta y líquido amniótico; E: calcificaciones placentarias; F: polihidroamnios. Servicio Medicina Materno Fetal Hospital Hernán Henríquez, Temuco. Chile.

sugerentes de CMVc, como las anormalidades de la sustancia blanca temporal anterior, las cavidades quísticas temporales anteriores y la dilatación focal del asta temporal de los ventrículos laterales ${ }^{55}$, son poco frecuentes.

Lo ideal sería realizar RM a todos los $\mathrm{RN}$ con $\mathrm{CMVc}$, ya que la presencia de las alteraciones descritas sería un indicador de enfermedad del SNC y, por lo tanto, de iniciar tratamiento antiviral. El acceso a la RM es difícil y requiere cooperación del paciente, por lo que habitualmente se realiza con sedación. Se ha logrado desarrollar protocolos sin sedación en $\mathrm{RN}$, con excelentes resultados ${ }^{149}$, y actualmente se utilizan en varios centros de nuestro país ${ }^{150}$. Consisten en alimentar al RN 30 minutos antes de su ingreso al resonador para lograr que esté dormido al momento de iniciar el examen. Se envuelve en una manta, previa instalación de tapones en los oídos, o bien se utiliza un inmovilizador pediátrico especial con sellado al vacío. El protocolo de RM tiene las secuencias estándar de encéfalo, pero se modifican los parámetros de adquisición para 


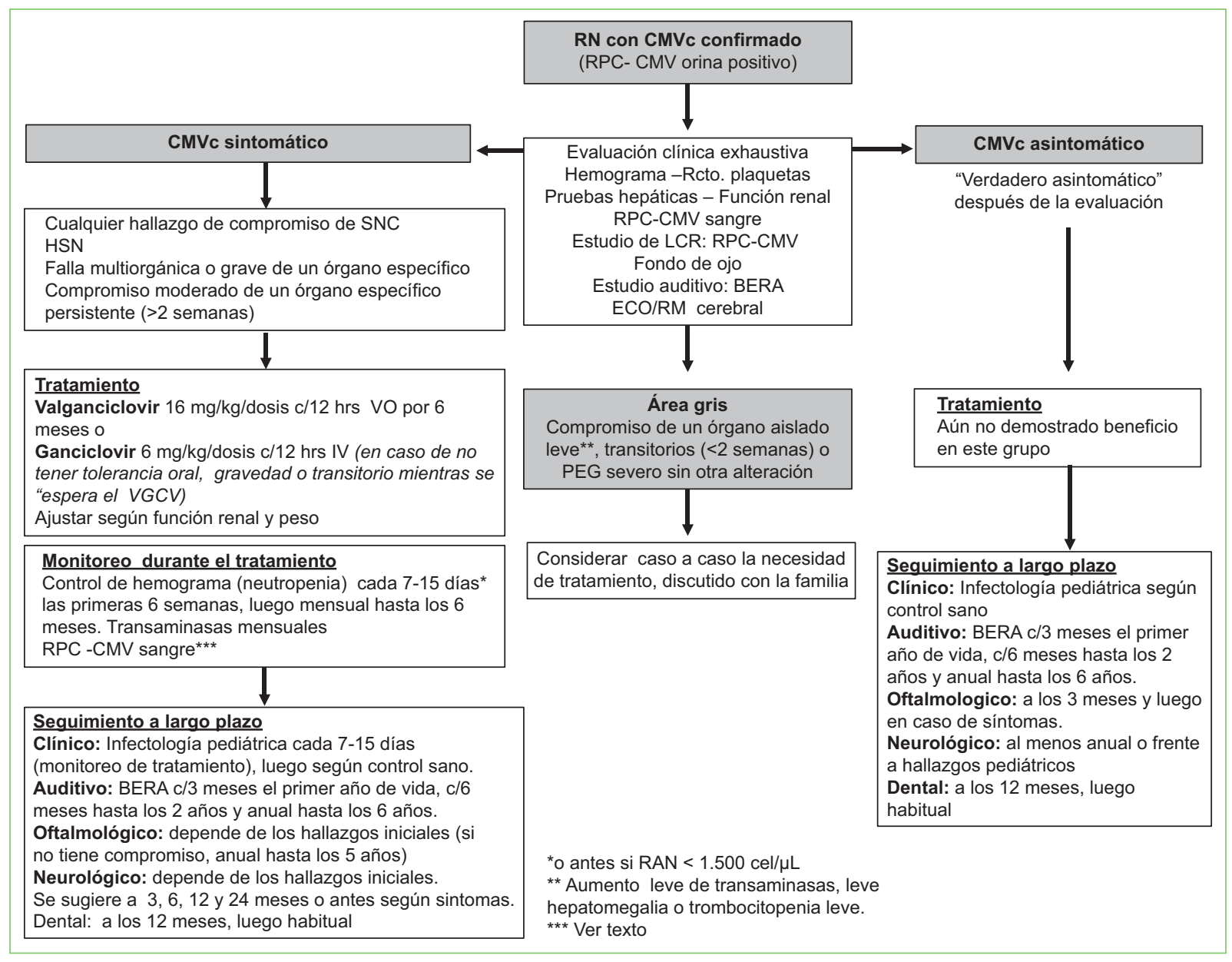

Figura 6. Algoritmo diagnóstico, tratamiento y seguimiento de RN con CMVc.

permitir una mejor visualización de las estructuras encefálicas poco mielinizadas del RN.

\section{EVALUACIÓN AUDITIVA}

El CMVc es la causa infecciosa más frecuente de hipoacusia congénita no genética, ocurriendo en el 7\% al $15 \%$ de la totalidad de los casos. Entre el $30 \%$ y el $65 \%$ de los RN sintomáticos presentan hipoacusia sensorioneural: el $70 \%$ de ellos al nacer, el $63 \%$ evoluciona con mayor compromiso en el tiempo y un tercio presentan hipoacusia sensorioneural de inicio tardío ${ }^{63}$. De los RN con CMVc asintomáticos, entre el $10 \%$ y el $15 \%$ presentan hipoacusia sensorioneural, el $50 \%$ de ellos evolucionan con deterioro de su función auditiva y el $18,2 \%$ presentan hipoacusia de inicio tardío en el seguimiento a 6 años ${ }^{30}$. Por ello, es fundamental el seguimiento a largo plazo en ambos escenarios.
La patogénesis y los mecanismos por los cuales se desarrollará el daño auditivo en estos pacientes, especialmente en los asintomáticos, no son del todo conocidos. Si bien se sabe que el CMV tiene un tropismo especial por la cóclea, en el último tiempo se ha encontrado también evidencia incipiente de compromiso vestibular $^{151,152}$.

La evaluación auditiva de cribado en un RN sano puede hacerse mediante las emisiones otoacústicas 0 los potenciales evocados auditivos de tronco (PEAT) automatizados, de acuerdo con la ausencia o la presencia de factores de riesgo de hipoacusia, respectivamente. Estas dos técnicas, ampliamente reconocidas, evalúan funciones diferentes. Las emisiones otoacústicas detectan la función de las células ciliadas externas de la cóclea; por lo tanto, ante el daño de las células ciliadas internas o de la vía retrococlear (nervio auditivo y tronco), las emisiones otoacústicas darán un resultado «pasa», informando un estudio auditivo 


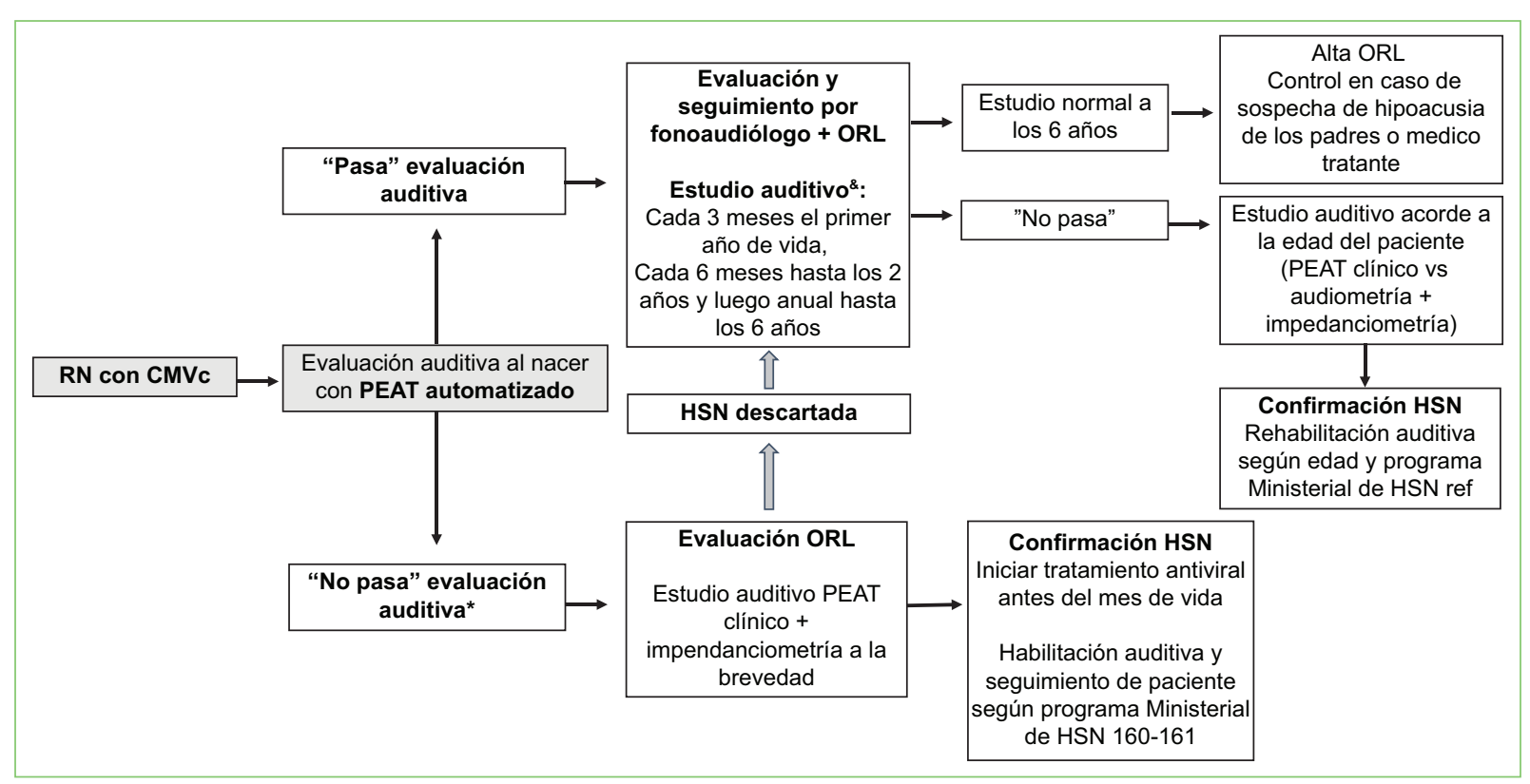

Figura 7. Evaluación auditiva y seguimiento audiológico de pacientes con CMVc.

ORL: otorrinolaringólogo; PEAT: potenciales evocados auditivos de tronco.

*PEAT automatizado referido en dos oportunidades. HSN: hipoacusia sensorioneural

\&Estudio auditivo de seguimiento: PEAT automatizado.

falsamente normal. Los PEAT automatizados permiten evaluar la actividad del nervio auditivo y otras estructuras a nivel del tronco cerebral tras una estimulación acústica estandarizada, siendo el criterio de «pase» la presencia de onda $V$ en el registro luego de una estimulación acústica de entre 35 y $40 \mathrm{~dB} \mathrm{HL}{ }^{153}$.

Los RN con diagnóstico de CMVc deben ser evaluados con PEAT automatizados como método de tamizaje, ya que se describe la presencia de neuropatía auditiva en estos niños, presentando un examen de emisiones otoacústicas con resultado "pasa» falsamente normal154.

En caso de que el RN con infección por CMV refiera el PEAT automatizado en dos oportunidades, debe ser evaluado por el otorrinolaringólogo y realizar un PEAT clínico más una impedanciometría (descarta la hipoacusia de conducción por problemas del oído medio), para confirmar la hipoacusia sensorioneural a la brevedad. Los objetivos actuales del Joint Committee on Infant Hearing $(\mathrm{JClH})$ se definen con el algoritmo «1-2-3 meses»: 1) tamizaje auditivo completado como máximo al mes de nacido con el objetivo de iniciar un tratamiento antiviral en el caso de CMVc; 2) diagnóstico audiológico establecido por un otorrinolaringólogo, completado a no más tardar de los 2 meses; y 3) intervención temprana de apoyo auditivo, no más tarde de los 3 meses $^{155}$. El tratamiento de la hipoacusia sensorioneural moderada, grave y profunda está garantizado por el Ministerio de Salud de Chile en los niños menores de 4 años ${ }^{156}$, así como también está garantizado el tratamiento de la hipoacusia sensorioneural bilateral en prematuros ${ }^{157}$.

En el caso de «pasar» las pruebas de cribado auditivo, el RN con CMVc debe continuar en seguimiento por el otorrinolaringólogo con evaluación auditiva seriada (Fig. 7).

\section{EVALUACIÓN OFTALMOLÓGICA}

Se debe realizar fondoscopia por un oftalmólogo pediátrico o con experiencia en RN. Se han descrito alteraciones en la evaluación en cerca del $20 \%$ de los casos de RN con CMVc sintomáticos ${ }^{158,159}$. La principal manifestación es la coriorretinitis, presente en el $10 \%$ al $21 \%{ }^{118,158}$. Otros hallazgos son la hemorragia y cicatrices retinianas (13\%), y la atrofia óptica (10\%). El pronóstico visual es peor en los RN con CMVc sintomáticos que en los asintomáticos (29\% vs. $1,2 \%$, respectivamente) ${ }^{158,160,161}$.

\section{EVALUACIÓN NEUROLÓGICA}

De los pacientes con infección in utero, alrededor del $10 \%$ van a presentar signos y síntomas clínicos neurológicos en el período neonatal (CMVc sintomático). Los principales hallazgos en los primeros días de vida son 


\section{Recomendación \# 6: evaluación del RN con CMVc}

- Exploración física completa, antropometría.

- Exámenes generales (recomendación fuerte, alta calidad de evidencia):

- Hemograma completo con recuento plaquetario.

- Pruebas de función hepática: AST, ALT, GGT, bilirrubinemia total y directa.

- Pruebas de función renal: creatininemia, nitrógeno ureico en sangre, orina completa.

- Estudio virológico:

- PCR-CMV cuantitativa en sangre total, que complementa el diagnóstico realizado por PCR-CMV en orina. Considerar que si es negativa no descarta la infección congénita (recomendación débil, baja calidad de evidencia).

- Estudio de LCR (recomendación fuerte, muy baja calidad de evidencia).

- Análisis físico-químico/citológico.

- PCR-CMV en LCR.

- Evaluación auditiva: PEAT automatizados (recomendación fuerte, alta calidad de evidencia).

- Evaluación oftalmológica (recomendación fuerte, alta calidad de evidencia).

- Evaluación neurológica: por neurólogo infantil o médico entrenado en evaluación neurológica del RN (recomendación fuerte, alta calidad de evidencia).

- Neuroimágenes: ecografía cerebral (recomendación fuerte, alta calidad de evidencia) o RM (recomendación fuerte, moderada calidad de evidencia).

la microcefalia (21-50\%), la presencia de convulsiones $(5-10 \%)$ y la coriorretinitis $(0-20 \%)^{96}$. Se deben evaluar, dirigidamente, el perímetro cefálico, la presencia de compromiso de consciencia, el tono axial, el control cefálico, los reflejos arcaicos y la succión, y las alteraciones vestibulares (difíciles de evaluar en el $\mathrm{RN})^{162}$, por lo que el examen neurológico de un paciente con CMVc debe ser idealmente realizado por un neurólogo infantil o un médico entrenado en este aspecto.

Se debe sospechar infección por CMVc en caso de alteraciones compatibles en las neuroimágenes 0 de convulsiones neonatales sin otra causa atribuible, en cuyo caso se recomienda estudio idealmente con videomonitoreo electroencefalográfico.

\section{Tratamiento del recién nacido}

Las complicaciones auditivas y neurológicas asociadas al CMVc continúan desarrollándose a lo largo de los primeros años de vida, por lo que el principal objetivo de la supresión viral posnatal con GCV/VGCV es prevenir o mejorar algunas de estas secuelas. Si bien la literatura científica ${ }^{2,4,96}$ recomienda el tratamiento antiviral en los casos moderados 0 graves, el tratamiento de los RN que se encuentran en el área "gris» definida en este consenso es más controversial, y deben ser evaluados caso a caso y discutidos con la familia los riesgos frente a los beneficios (Tabla 6).

En el año 2003, Kimberlin et al. ${ }^{163}$ establecieron que el tratamiento durante 6 semanas con GCV intravenoso, antes de los 30 días de vida, en RN con más de 32 semanas de gestación, logró una clara mejoría en el resultado auditivo y neurológico a los 12 meses, en comparación con los niños no tratados. El mayor efecto adverso observado fue la neutropenia en dos terceras partes de los casos. El estudio que cambió la forma de tratamiento del $\mathrm{CMV}_{\mathrm{c}}$ fue el último realizado por este

\section{Recomendación \# 7: tratamiento del RN con} CMVc

- Se recomienda el tratamiento antiviral a todos los $\mathrm{RN}$ con CMVc sintomáticos moderados y graves (recomendación fuerte, alta calidad de evidencia).

- La indicación de tratamiento de los pacientes con CMVc leve (área "gris») debe ser analizada caso a caso (Fig. 6) (recomendación débil, baja calidad de evidencia).

- El tratamiento debe ser con VGCV. En caso de que no se pueda usar la vía oral o no se cuente con el medicamento, utilizar GCV y luego cambiar a VGCV (recomendación fuerte, alta calidad de evidencia).

- Dosis de VGCV: 16 mg/kg cada 12 horas por vía oral (Tabla 5).

- Dosis de GCV: 6 mg/kg cada 12 horas por vía intravenosa (de elección vía central).

- Se debe ajustar las dosis de antiviral según la función renal.

- La duración del tratamiento con VGCV debe ser por 6 meses (recomendación fuerte, alta calidad de evidencia), y se iniciará idealmente antes de los 30 días de vida (recomendación fuerte, moderada calidad de evidencia).

- El tratamiento con VCGV/GCV en neonatos de menos de 32 semanas de edad gestacional debe ser discutido con el infectólogo pediatra (recomendación fuerte, moderada calidad de evidencia).

- Hasta ahora no hay evidencia que recomiende el tratamiento de los RN con CMVc «verdadero asintomático". 
Tabla 5. Consideraciones para la preparación y administración de valganciclovir

Si no cuenta con la suspensión o jarabe, se debe mandar a preparar a farmacia, como recetario magistral. Concentración habitual en RN: $30050 \mathrm{mg} / \mathrm{mL}$ (puede prepararse a una mayor concentración según necesidad)

Guardar en el refrigerador a $2-8^{\circ} \mathrm{C}$. No congelar.

La estabilidad de la suspensión de VGCV tiene una duración de 30 días, bajo condiciones adecuadas de almacenamiento y temperatura.

Administrar la dosis directamente en la boca, no mezclar con ningún líquido (agua, leche o jugos) antes de dar la dosis. Se puede administrar por sonda nasogástrica o gastrostomía.

Si faltara una dosis, dar la dosis tan pronto como sea posible. Si ya es la hora de la siguiente dosis, no se debe duplicar, simplemente no administrar la dosis olvidada

Si se derrama o tiene contacto con la piel, se debe lavar la zona con abundante agua y jabón.

Después de su manipulación se deben lavar las manos.

Tabla 6. Brechas en el conocimiento de la infección por CMV en la mujer embarazada y RN

\footnotetext{
Epidemiología

Realizar nuevos estudios de prevalencia de CMV en la población en edad fértil, mujeres embarazadas y RN en Chile.

Diagnóstico

Avanzar en el diagnóstico de laboratorio de la infección por CMV en la mujer embarazada (test de avidez y estudio molecular en sangre y líquido amniótico)

Realizar un estudio diagnóstico exhaustivo del RN para identificar los signos y síntomas sutiles que permitan clasificar adecuadamente a los RN sintomáticos.

Tratamiento

Se requiere de más estudios randomizados controlados sobre otras alternativas terapéuticas en la mujer embarazada. Se desconocen los mejores esquemas para gestantes con inmunodeficiencias, usuarias de corticosteroides o falla renal. Aún no existe información sobre el tratamiento de los RN "verdaderamente" asintomáticos o si existe algún impacto en el tratamiento de CMVc después de los 30 días de vida.

Prevención

Conocimiento de la enfermedad y de su prevención tanto de las mujeres embarazadas como de los equipos de salud Ausencia de vacunas hasta ahora, aún en fases preliminares.
}

grupo, en el cual, también en RN con menos de 32 semanas de gestación, se comparó el uso de VGCV (16 mg/kg por dosis cada $12 \mathrm{~h}$ ) por 6 meses con el de GCV intravenoso (6 mg/kg por dosis) durante 6 semanas, y se observó una mejoría significativa de la audición total y del neurodesarrollo (cognitivo, lenguaje y motor) a los 24 meses de vida en el grupo que recibió VGCV. Por otra parte, la incidencia de neutropenia fue similar en los tratados con placebo y con VGCV, lo que sugiere que la neutropenia en los RN tratados con este antiviral puede ser, al menos en parte, atribuible a la infección por el CMV ${ }^{164}$. Con esta evidencia, el tratamiento actual del RN con CMVc es con VGCV por 6 meses, pudiendo utilizarse GCV si no se dispone del jarabe o la suspensión de VGCV, en pacientes críticos o sin posibilidad de la vía oral.

Aún no está clara la utilidad del tratamiento posterior a los 30 días de vida en los RN que evolucionan con hipoacusia sensorioneural en el tiempo. Existen dos estudios en curso en este escenario, cuyos resultados preliminares han sido contradictorios (Chung $\mathrm{P}$, et al., ClinicalTrials.gov Identifier: NCT02005822, y Kimberlin D, et al., ClinicalTrials.gov Identifier: NCT01649869); por ahora, los estudios se han realizado en neonatos con menos de 32 semanas de edad gestacional.

\section{MONITORIZACIÓN DE LA RESPUESTA A LA TERAPIA MEDIANTE LA CARGA VIRAL}

El seguimiento de la carga viral para la evaluación de la respuesta durante el tratamiento es aún discutido. Su detección al inicio del tratamiento se ha correlacionado con la presencia de síntomas en el RN, pero el valor de corte aún no está claramente establecido ${ }^{139}$. Marsico et al. ${ }^{138}$ publicaron un análisis de la medición de la carga viral en los pacientes incluidos en los dos estudios clínicos prospectivos que evaluaron el uso de VGCV en lactantes con CMVc sintomático ${ }^{134}$. Midieron la carga viral basal, durante y al finalizar el tratamiento. La supresión viral sostenida durante 6 meses de terapia se correlacionó con mejores resultados auditivos a los 6,12 y 24 meses $(p=0,01, p=0,0007$ y $p=0,04$, respectivamente). Se considera una disminución significativa un cambio de al menos 0,5 log a la semana de tratamiento efectivo ${ }^{138}$. La progresión del compromiso de órganos diana o la ausencia de disminución significativa de la carga viral deben hacer sospechar una alteración inmunitaria basal del paciente (inmunodeficiencia primaria o secundaria), una resistencia al tratamiento antiviral (GCV/VGCV) o una combinación de ambas, siendo más probable la primera situación.

En los RN sin compromiso grave ni multiorgánico se sugiere un control a los 3 y 6 meses de tratamiento, si es posible, debido a que los pacientes que no logran la supresión viral durante el tratamiento son los que tienen mayor riesgo de secuelas ${ }^{138}$. Se debe verificar que exista una adecuada adherencia al tratamiento 
antiviral y que la preparación y la administración del jarabe de VGCV sean correctas.

\section{MONITORIZACIÓN DE EVENTOS ADVERSOS}

El tratamiento con GCV/VGCV debe ser monitorizado porque se han descrito eventos adversos, como distintos grados de insuficiencia medular (neutropenia, anemia, trombocitopenia), elevación transitoria de las transaminasas y compromiso de la función renal ${ }^{134,164}$.

La neutropenia es el efecto adverso más común y se puede presentar en cualquier momento, siendo más frecuente durante las primeras 6 semanas. Por ello, durante este período se deben realizar controles seriados. Si la neutropenia es $<750$ céls $/ \mathrm{mm}^{3}$ se puede disminuir la dosis de antiviral al $50 \%$ y controlar a la semana. Sin embargo, si la neutropenia es profunda (500 céls $/ \mathrm{mm}^{3}$ ) se debe suspender hasta evidenciar el alza $^{134}$. En general, los recuentos celulares comienzan a recuperarse dentro de los 3 a 7 días posteriores a la suspensión del fármaco. En los pacientes con citopenias profundas se puede considerar el tratamiento con factores de crecimiento hematopoyéticos, con una a tres dosis en días consecutivos, antes de ser necesario suspenderlo ${ }^{134}$. El tiempo total de tratamiento se considera descontando los días de las interrupciones por neutropenia y no requiere reiniciar el tratamiento desde cero. No se debe iniciar el tratamiento si el recuento absoluto de neutrófilos es $<500$ céls $/ \mathrm{mm}^{3}$, el de plaquetas es $<25.000 / \mathrm{mm}^{3}$ o la hemoglobina es $<8 \mathrm{~g} /$ $\mathrm{d}^{165}$. Se sugiere un control cada 7 a 15 días durante las primeras 6 semanas (dependiendo de la condición del paciente) y posteriormente una vez al mes hasta finalizar la terapia ${ }^{134,164}$. Durante el tratamiento se sugiere controlar los valores de transaminasas mensualmente, ya que se puede observar un aumento transitorio ${ }^{134}$.

\section{SEguimiento deL LACTANTE y DEL NIÑO CON CMVC Seguimiento clínico pediátrico}

Los controles clínicos deben ser realizados por un infectólogo pediatra o por un médico entrenado en infecciones congénitas. La frecuencia debe ser cada 7-15 días las primeras 6 semanas y luego mensual hasta los 6 meses para la evaluación de los exámenes solicitados e ir ajustando la dosis según el peso si se encuentra en tratamiento con VGCV. Luego, según el control del niño sano habitual, poniendo énfasis en la evaluación del desarrollo psicomotor, y coordinar los controles con otorrinolaringología, oftalmología, neurología o dental según corresponda.

\section{Seguimiento auditivo}

El seguimiento de pacientes con hipoacusia por CMVc ha demostrado que el «peor oído» suele avanzar en su pérdida auditiva más rápido que el «mejor oído», llegando a hipoacusia sensorioneural profunda cerca de los 4 años. Lanzieri et al. ${ }^{166}$ describieron el seguimiento de pacientes con CMVc definidos como asintomáticos (al examen clínico) hasta los 18 años, demostrando que la pérdida auditiva puede seguir siendo progresiva, incluso hasta esa edad.

La recomendación actual de seguimiento auditivo de un RN con CMVc que pasa el cribado auditivo al nacer (con PEAT automatizados) debe ser cada 3 meses el primer año, cada 6 meses el segundo año de vida y luego anual hasta al menos los 6 años. Posteriormente, se puede realizar una evaluación ante la sospecha de hipoacusia por parte de los cuidadores o del médico tratante (Fig. 6). La forma de evaluación de la hipoacusia va a depender de la edad y la colaboración del paciente $^{167}$ (Fig. 6).

Por otra parte, las alteraciones vestibulares descritas en los pacientes con CMVc, al igual que la hipoacusia sensorioneural, pueden ser congénitas 0 de inicio tardío, y presentarse de forma variable (unilateral o bilateral, simétricas 0 asimétricas), sin que exista necesariamente hipoacusia concomitante. La evaluación vestibular en niños de corta edad es difícil, por lo que no se describen (o no se encuentran) alteraciones evidentes en el RN. A partir de los 3 meses, cuando exista sostén cefálico, se puede realizar estudio con potenciales vestibulares evocados miogénicos cervicales. Este examen registra la función vestibular sacular del oído interno. En la medida en que el niño vaya creciendo podrá evaluarse la función vestibular con otros estudios, como el sillón rotatorio (función de canales semicirculares) o el vHIT (video head impulse), que mide la función de cada uno de los canales semicirculares de forma aislada ${ }^{151,168}$. No obstante, estas evaluaciones requieren la cooperación del paciente y un examinador experimentado. La tradicional prueba calórica no está indicada en los niños por las molestias asociadas a ella.

La evaluación del neurodesarrollo con énfasis en el equilibrio resulta fundamental en los niños con CMVc. Un desarrollo alterado podría sugerir alguna alteración vestibular en esta población. 


\section{Seguimiento oftalmológico}

Los datos del seguimiento oftalmológico en general se basan en pocos estudios, siendo el principal factor de riesgo de mal pronóstico visual la presencia de síntomas al nacer, en especial el compromiso del SNC. Esta escasez de datos ha dificultado la elaboración de recomendaciones claras sobre el seguimiento oftalmológico que debe proporcionarse a los lactantes con infección por $\mathrm{CMVc}^{159}$.

Recomendamos la evaluación oftalmológica dependiendo de los hallazgos al nacer y al menos una vez al año hasta los 5 años en los RN sintomáticos. La aparición de lesiones oculares en los RN asintomáticos es sumamente infrecuente, por lo que se recomienda un seguimiento a los 3 meses (si no se trata) y luego solo en caso de aparición de síntomas (Fig. 6).

\section{Seguimiento neurológico}

A largo plazo, las principales secuelas neurológicas de la infección por CMVc son la hipoacusia sensorioneural (v. apartado «Evaluación auditiva»), la disfunción vestibular, el retraso del desarrollo psicomotor, los trastornos del neurodesarrollo, la parálisis cerebral, la discapacidad intelectual, la microcefalia y la epilepsia ${ }^{169}$. Se han descrito trastornos del espectro autista con dos a tres veces más riesgo que la población general, trastornos del lenguaje y del aprendizaje, y déficit atencional; sin embargo, aún se requieren más estudios prospectivos para atribuir su causalidad ${ }^{170,171}$.

El principal factor de pronóstico neurológico a largo plazo es la edad gestacional al momento de la infección materna. Muy ocasionalmente se observan signos graves si la infección primaria ocurre después del primer trimestre de embarazo. En el estudio de Pass et al. ${ }^{172}$ se describe la evolución natural de la enfermedad en 35 niños con infección materna durante el primer trimestre. El $32 \%$ tuvo secuelas neurológicas, el $17 \%$ discapacidad intelectual y el $23 \%$ hipoacusia sensorioneural. Otros factores predictores de secuelas neurológicas a largo plazo son la presencia de síntomas en la evaluación inicial (recordando que los niños asintomáticos pueden presentar secuelas posteriores), la presencia de alteraciones en las neuroimágenes y la microcefalia ${ }^{147}$. En un estudio de seguimiento de 84 niños con CMVc se asoció la presencia de microcefalia, calcificaciones intracraneales o coriorretinitis con un $79 \%$ de secuelas mayores y solo un $7 \%$ de normalidad ${ }^{173}$. De los niños que presentaron otros signos neurológicos menos sugerentes de infección por CMV, como irritabilidad, hemorragia subaracnoidea, paresia facial o de cuerdas vocales e hidrocefalia, el $40 \%$ evolucionó a la normalidad y el $50 \%$ a secuelas mayores. Los niños con ausencia de signos neurológicos o sistémicos evolucionan el $81 \%$ con normalidad, el $16 \%$ con secuelas menores y el $3 \%$ con secuelas mayores $^{34}$.

Actualmente no se encuentran establecidas guías de seguimiento neurológico, por lo que recomendamos realizar una evaluación neurológica y del neurodesarrollo a los 3, 6, 12 y 24 meses en los RN con CMVc sintomáticos, y en los asintomáticos a los 12 y 24 meses, y luego según los hallazgos de la evaluación pediátrica (Fig. 6).

Se ha visto una posible asociación del CMVc con trastornos del espectro autista, trastornos de déficit atencional e hiperactividad, trastornos del aprendizaje y del lenguaje, de la función ejecutiva y otros trastornos del neurodesarrollo. Se recomienda evaluar a estos niños con controles habituales anuales por el pediatra, hasta al menos el ingreso a la etapa escolar, cuando los síntomas de estas patologías se hacen más evidentes, y derivación a neurología en caso de sospecha clínica ${ }^{170,171 .}$.

Los niños que tengan cuadros clínicos neurológicos establecidos, como convulsiones o parálisis cerebral, deben seguir los controles habituales según su neurólogo tratante.

\section{Seguimiento dental}

En ocasiones, en especial entre los pacientes sintomáticos, se producen alteraciones del esmalte de la dentición primaria. Estos pacientes tienen alteración de la coloración del esmalte y una mayor tendencia a la presencia de caries ${ }^{174,175}$, por lo que se recomienda una primera evaluación a los 6-12 meses de vida y luego según el control habitual o según los hallazgos (Fig. 6).

\section{Cribado en el recién nacido}

En la actualidad, las enfermedades detectables por pesquisa neonatal en nuestro país son la fenilcetonuria y el hipotiroidismo congénito, con frecuencias de $1 / 10.000$ y $1 / 3500$ RNV, respectivamente. Cada año nacen en Chile entre 15 y 20 niños con fenilcetonuria y cerca de 60 con hipotiroidismo congénito ${ }^{176}$.

La incorporación del CMVc a los programas de cribado universal aún es discutida internacionalmente $177-179$, a pesar de que su prevalencia estimada en Chile es mayor que la de otras enfermedades de 
cribado neonatal (2/1000 RNV, cerca de $2000 \mathrm{RNV})^{180}$. La ventaja principal del tamizaje universal para CMVc sería detectar en forma temprana la infección en pacientes asintomáticos o "clínicamente inaparentes» con riesgo de desarrollar hipoacusia sensorioneural de inicio tardío, y así realizar un seguimiento auditivo hasta la edad escolar, para poder intervenir en forma oportuna y mejorar el pronóstico ${ }^{178,179}$.

Otra estrategia de cribado descrita es la realizada en grupos de riesgo (targeted screening), en la cual se identifican los RN con mayor probabilidad de presentar CMVc, como son aquellos que "refieren» 0 "no pasan» en el estudio auditivo neonatal, en los que se estima una frecuencia de infección por CMV entre el 1\% y el $7 \%{ }^{113,114,181-183}$, con la limitación de que con esta estrategia no se identifican hasta el $43 \%$ de los niños que desarrollarán hipoacusia tardía relacionada con $\mathrm{CMV}^{112}$.

Cabe señalar, además, que quienes nacen con menos de 32 semanas de edad gestacional y menos de $1500 \mathrm{~g}$ de peso ${ }^{184}$ presentan un mayor riesgo de adquirir la infección por CMV de forma posnatal y presentar compromiso clínico significativo, como hepatitis, neutropenia, trombocitopenia o apariencia séptica, así como neumonía y enteritis, que son menos frecuentes, pero muy característicos. El cribado al nacimiento en este grupo permitiría detectar o descartar la infección congénita y, a su vez, realizar el diagnóstico diferencial adecuado de CMV posnatal, lo cual implica una diferencia sustancial en el manejo, el seguimiento y el pronóstico ${ }^{185}$.

Otros grupos de riesgo ya se han descrito previamente en este documento (v. apartado «Sospecha clínica en el recién nacido»).

En suma, un programa de cribado universal de infección por CMVc permitiría evaluar oportunamente al RN, considerar el tratamiento y realizar un seguimiento activo a largo plazo, con potenciales beneficios sociales y en salud pública, debido a la disminución de la carga y de los costos por discapacidad ${ }^{186}$. Los estudios de costo-beneficio realizados, tanto para cribado universal como para grupos de riesgo, han mostrado utilidad $^{187}$; sin embargo, en lugares con recursos limitados, el cribado universal pareciera ser impracticable por ahora, sobre todo porque el tratamiento del RN verdaderamente asintomático sigue siendo controversial. En nuestra realidad se podría recomendar una ampliación: el cribado en grupos de riesgo, como en aquellos RN que refieren el estudio auditivo al nacer, PEG graves 0 PEG no graves con algún otro síntoma, y prematuros extremos, tal como ya se hace en pacientes hijos de madres con sospecha de infección en el embarazo, RN con manifestaciones clínicas características e hijos de madres con infección por VIH.

\section{Conclusiones}

Actualmente se dispone de nuevos métodos diagnósticos y terapéuticos para la infección congénita por CMV, tanto en la madre como en el RN. Estos avances hacen que tengamos que replantearnos la forma en que debemos mirar esta enfermedad, desde su diagnóstico hasta el seguimiento a largo plazo.

Si bien es una patología conocida desde hace muchos años, la brecha en el conocimiento de la infección por CMV en el binomio (Tabla 6) limita la planificación de una estrategia de cribado, estudio diagnóstico, tratamiento y prevención. Es fundamental que existan iniciativas dirigidas a un muestreo representativo de infección por CMV en nuestra población, tanto durante el embarazo como en el período neonatal.

Se pueden sugerir diversas formas para pesquisar de manera oportuna esta enfermedad, y así mejorar su conocimiento y pronóstico:

- Las mujeres deben ser informadas sobre la infección por CMV durante el embarazo y la forma de establecer medidas de prevención adecuadas, siendo ideal realizar un cribado materno en el período periconcepcional y el primer trimestre, sobre todo en aquellas de mayor riesgo (seronegativas conocidas previas o trabajo con niños en edad preescolar).

- Ante la presencia de alteraciones ecográficas sospechosas durante el embarazo, deben hacerse todos los esfuerzos necesarios para establecer si ha habido infección materna o infección fetal, y el grado de afectación fetal, para establecer un tratamiento apropiado en la madre o identificar al $\mathrm{RN}$ al nacer.

- Por último, se debe contribuir a que todos los niños con infección congénita sean evaluados en forma exhaustiva para lograr identificar a los «verdaderos asintomáticos» y garantizar el tratamiento en aquellos que corresponda, junto con un adecuado seguimiento a largo plazo.

\section{Agradecimientos}

A la Fundación StopCMV.

\section{Financiamiento}

Los autores declaran no tener financiamiento. 


\section{Conflicto de intereses}

Los autores declaran no tener conflictos de intereses.

\section{Responsabilidades éticas}

Protección de personas y animales. Los autores declaran que para esta investigación no se han realizado experimentos en seres humanos ni en animales.

Confidencialidad de los datos. Los autores declaran que han seguido los protocolos de su centro de trabajo sobre la publicación de datos de pacientes.

Derecho a la privacidad y consentimiento informado. Los autores han obtenido el consentimiento informado de los pacientes y/o sujetos referidos en el artículo. Este documento obra en poder del autor de correspondencia.

\section{Bibliografía}

1. Manicklal S, Emery VC, Lazzarotto T, Boppana SB, Gupta RK. The "silent” global burden of congenital cytomegalovirus. Clin Microbiol Rev. 2013;26:86-102

2. Rawlinson WD, Boppana SB, Fowler KB, Kimberlin DW, Lazzarotto T, Alain $\mathrm{S}$, et al. Congenital cytomegalovirus infection in pregnancy and the neonate: consensus recommendations for prevention, diagnosis, and therapy. Lancet Infect Dis. 2017;17:e177-88.

3. Leruez-Ville M, Magny JF, Couderc S, Pichon C, Parodi M, Bussieres L, et al. Risk factors for congenital cytomegalovirus infection following primary and nonprimary maternal infection: a prospective neonatal screening study using polymerase chain reaction in saliva. Clin Infect Dis. 2017:65:398-404.

4. Baquero-Artigao F, Grupo de Estudio de la Infección Congénita por Citomegalovirus de la Sociedad Espanola de Infectología Pediátrica. Consensus document from the Spanish Society of Paediatric Infectious Diseases (SEIP) on the diagnosis and treatment of congenital cytomegalovirus infection. An Pediatr (Barc). 2009;71:535-47.

5. Morton CC, Nance WE. Newborn hearing screening - a silent revolution. N Engl J Med. 2006;354:2151-64.

6. Foulon I, De Brucker Y, Buyl R, Lichtert E, Verbruggen K, Pierard D, et al. Hearing loss with congenital cytomegalovirus infection. Pediatrics. 2019;144:e20183095

7. Zuhair M, Smit GSA, Wallis G, Jabbar F, Smith C, Devleesschauwer B, et al. Estimation of the worldwide seroprevalence of cytomegalovirus: a systematic review and meta-analysis. Rev Med Virol. 2019;29:e2034.

8. Vial P, Torres J, Stagno S, González F, Donoso E, Alford C, et al. Estudio serológico de citomegalovirus, virus del herpes simple y de la rubéola, hepatitis B y Toxoplasma gondii en dos poblaciones de gestantes en Santiago, Chile. Bol Oficina Sanit Panam. 1985:99:528-38.

9. Suárez M, Briones H, Alarcón G, Aliaga P, Grunberg A, Diego S, et al Virus del herpes simple y citomegalovirus en universitarias chilenas embarazadas. Bol Oficina Sanit Panam. 1991:111:319-22.

10. Yamamoto M, Prado $P$, Wilhelm J, Bradford R, Lira F, Insunza F, et al. Alta prevalencia de IgG anticitomegalovírus en 583 embarazos: Hospital Padre Hurtado. Rev Chil Obstet Ginecol. 2009;74:102-6.

11. Mussi-Pinhata MM, Yamamoto AY, Aragon DC, Duarte G, Fowler KB Boppana $S$, et al. Seroconversion for cytomegalovirus infection during pregnancy and fetal infection in a highly seropositive population: "The BraCHS Study". J Infect Dis. 2018;218:1200-4.

12. Puhakka $L$, Lappalainen $M$, Lonnqvist $T$, Niemensivu $R$, Lindahl $P$, Nieminen $\mathrm{T}$, et al. The burden of congenital cytomegalovirus infection: a prospective cohort study of 20000 infants in Finland. J Pediatric Infect Dis Soc. 2019:8:205-12.

13. Feldman B, Yinon Y, Tepperberg Oikawa M, Yoeli R, Schiff E, Lipitz S. Pregestational, periconceptional, and gestational primary maternal cytomegalovirus infection: prenatal diagnosis in 508 pregnancies. Am J Obstet Gynecol. 2011;205:342e1-6.

14. Revello MG, Gerna G. Diagnosis and management of human cytomegalovirus infection in the mother, fetus, and newborn infant. Clin Microbio Rev. 2002;15:680-715.
15. Hadar E, Yogev Y, Melamed N, Chen R, Amir J, Pardo J. Periconceptional cytomegalovirus infection: pregnancy outcome and rate of vertical transmission. Prenat Diagn. 2010;30:1213-6.

16. Chatzakis $C$, Ville $Y$, Makrydimas G, Dinas $K$, Zavlanos A, Sotiriadis A. Timing of primary maternal cytomegalovirus infection and rates of vertical transmission and fetal consequences. Am J Obstet Gynecol. 2020;223:870-83e11.

17. Cannon MJ, Schmid DS, Hyde TB. Review of cytomegalovirus seroprevalence and demographic characteristics associated with infection. Rev Med Virol. 2010;20:202-13.

18. Fowler KB, Stagno S, Pass RF. Maternal immunity and prevention of congenital cytomegalovirus infection. JAMA. 2003;289:1008-11.

19. Kenneson A, Cannon MJ. Review and meta-analysis of the epidemiology of congenital cytomegalovirus (CMV) infection. Rev Med Virol. 2007:17:253-76

20. Maltezou PG, Kourlaba G, Kourkouni E, Luck S, Blazquez-Gamero D, Ville $Y$, et al. Maternal type of CMV infection and sequelae in infants with congenital CMV: systematic review and meta-analysis. J Clin Virol. 2020;129:104518.

21. Faure-Bardon V, Magny JF, Parodi M, Couderc S, Garcia P, Maillotte AM, et al. Sequelae of congenital cytomegalovirus following maternal primary infections are limited to those acquired in the first trimester of pregnancy. Clin Infect Dis. 2019;69:1526-32.

22. Ross SA, Fowler KB, Ashrith G, Stagno S, Britt WJ, Pass RF, et al. Hearing loss in children with congenital cytomegalovirus infection born to mothers with preexisting immunity. J Pediatr. 2006;148:332-6.

23. Townsend $\mathrm{CL}$, Forsgren $\mathrm{M}$, Ahlfors $\mathrm{K}$, Ivarsson SA, Tookey PA, Peckham CS. Long-term outcomes of congenital cytomegalovirus infection in Sweden and the United Kingdom. Clin Infect Dis. 2013;56:1232-9.

24. Lanzieri TM, Dollard SC, Bialek SR, Grosse SD. Systematic review of the birth prevalence of congenital cytomegalovirus infection in developing countries. Int J Infect Dis. 2014;22:44-8.

25. Estripeaut D, Moreno Y, Ahumada Ruiz S, Martinez A, Racine JD, Saez-Llorens X. Seroprevalence of cytomegalovirus infection in puerperal women and its impact on their newborns. An Pediatr (Barc). 2007;66:135-9.

26. Rico A, Dollard SC, Valencia D, Corchuelo S, Tong VT, Laiton-Donato K, et al. Epidemiology of cytomegalovirus infection among mothers and infants in Colombia. J Med Virol. 2021;93:6393-7.

27. Luchsinger V, Suarez M, Schultz R, Barraza P, Guzman M, Terrada $L$, et al. [Incidence of congenital cytomegalovirus infection in newborn infants of different socioeconomic strata]. Rev Med Chil. 1996;124:403-8.

28. Leruez-Ville M, Guilleminot T, Stirnemann J, Salomon LJ, Spaggiari E, Faure-Bardon V, et al. Quantifying the burden of congenital cytomegalovirus infection with long-term sequelae in subsequent pregnancies of women seronegative at their first pregnancy. Clin Infect Dis. 2020;71:1598-603

29. Dollard SC, Grosse SD, Ross DS. New estimates of the prevalence of neurological and sensory sequelae and mortality associated with congenital cytomegalovirus infection. Rev Med Virol. 2007;17:355-63.

30. Fowler KB, McCollister FP, Dahle AJ, Boppana S, Britt WJ, Pass RF. Progressive and fluctuating sensorineural hearing loss in children with asymptomatic congenital cytomegalovirus infection. J Pediatr. 1997; 130:624-30.

31. Pass RF, Stagno S, Myers GJ, Alford CA. Outcome of symptomatic congenital cytomegalovirus infection: results of long-term longitudinal follow-up. Pediatrics. 1980;66:758-62.

32. Boppana SB, Ross SA, Fowler KB. Congenital cytomegalovirus infection: clinical outcome. Clin Infect Dis. 2013;57(Suppl 4):S178-81.

33. Instituto Nacional de Estadísticas, Chile. Estadísticas vitales. Disponible en: https://www.ine.cl/estadisticas/sociales/demografia-y-vitales/nacimientos-matrimonios-y-defunciones

34. Cheeran MC, Lokensgard JR, Schleiss MR. Neuropathogenesis of congenital cytomegalovirus infection: disease mechanisms and prospects for intervention. Clin Microbiol Rev. 2009;22:99-126.

35. Nigro G, Anceschi MM, Cosmi EV, Congenital Cytomegalic Disease Collaborating Group. Clinical manifestations and abnormal laboratory findings in pregnant women with primary cytomegalovirus infection. $\mathrm{Br} \mathrm{J}$ Obstet Gyneol. 2003;110:572-7.

36. Torii $Y$, Yoshida S, Yanase $Y$, Mitsui T, Horiba K, Okumura T, et al. Serological screening of immunoglobulin $\mathrm{M}$ and immunoglobulin $\mathrm{G}$ during pregnancy for predicting congenital cytomegalovirus infection. BMC Pregnancy Childbirth. 2019;19:205.

37. Juhl D, Vockel A, Luhm J, Ziemann M, Hennig H, Gorg S. Comparison of the two fully automated anti-HCMV IgG assays: Abbott Architect CMV $\operatorname{lgG}$ assay and Biotest anti-HCMV recombinant IgG ELISA. Transfus Med. 2013;23:187-94

38. Revello MG, Vauloup-Fellous C, Grangeot-Keros L, van Helden J, Dickstein Y, Lipkin I, et al. Clinical evaluation of new automated cytomegalovirus IgM and IgG assays for the Elecsys $₫$ analyser platform. Eur $J$ Clin Microbiol Infect Dis. 2012;31:3331-9. 
Rev Chil Obstet Ginecol. 2021;86(6)

39. Sellier $Y$, Guilleminot T, Ville $Y$, Leruez-Ville M. Comparison of the LIAISON® CMV IgG Avidity II and the VIDAS $®$ CMV IgG Avidity II assays for the diagnosis of primary infection in pregnant women. J Clin Virol. 2015;72:46-8.

40. Leruez-Ville M, Foulon I, Pass R, Ville Y. Cytomegalovirus infection during pregnancy: state of the science. Am J Obstet Gynecol. 2020;223:330-49.

41. Leruez-Ville M, Sellier Y, Salomon LJ, Stirnemann JJ, Jacquemard F, Ville Y. Prediction of fetal infection in cases with cytomegalovirus immunoglobulin $M$ in the first trimester of pregnancy: a retrospective cohort. Clin Infect Dis. 2013;56:1428-35.

42. Revello MG Zavattoni M, Sarasini A, Percivalle E, Simoncini L, Gerna G. Human cytomegalovirus in blood of immunocompetent persons during primary infection: prognostic implications for pregnancy. J Infect Dis. 1998:177:1170-5.

43. Garrigue I, Doussau A, Asselineau J, Bricout H, Couzi L, Rio C, et al Prediction of cytomegalovirus (CMV) plasma load from evaluation of CMV whole-blood load in samples from renal transplant recipients. J Clin Microbiol. 2008:46:493-8.

44. Cofré F, Delpiano L, Labrana Y, Reyes A, Sandoval A, Izquierdo G. Síndrome de TORCH: enfoque racional del diagnóstico y tratamiento pre y post natal. Recomendaciones del Comité Consultivo de Infecciones Neonatales Sociedad Chilena de Infectología, 2016. Rev Chil Infectol. 2016;33:191-216.

45. Penner J, Hernstadt $H$, Burns JE, Randell P, Lyall $H$. Stop, think SCORTCH: rethinking the traditional 'TORCH' screen in an era of re-emerging syphilis. Arch Dis Child. 2021;106:117-24.

46. Leruez-Ville M, Ren S, Magny JF, Jacquemard F, Couderc S, Garcia P, et al. Accuracy of prenatal ultrasound screening to identify fetuses infected by cytomegalovirus which will develop severe long-term sequelae. Ultrasound Obstet Gynecol. 2021;57:97-104.

47. Khalil A, Sotiriadis A, Chaoui R, da Silva Costa F, D'Antonio F, Heath PT, et al. ISUOG Practice Guidelines: role of ultrasound in congenital infection. Ultrasound Obstet Gynecol. 2020;56:128-51.

48. Leruez-Ville M, Ville Y. Fetal cytomegalovirus infection. Best Pract Res Clin Obstet Gynaecol. 2017;38:97-107.

49. Faure-Bardon V, Millischer AE, Deloison B, Sonigo $P$, Grevent D, Salomon $\mathrm{L}$, et al. Refining the prognosis of fetuses infected with cytomegalovirus in the first trimester of pregnancy by serial prenatal assessment: a single-centre retrospective study. Br J Obstet Gynecol. 2020;127:355-62.

50. Vintzileos AM, Campbell WA, Nochimson DJ, Weinbaum PJ. Degree of oligohydramnios and pregnancy outcome in patients with premature rupture of the membranes. Obstet Gynecol. 1985;66:162-7.

51. La Torre R, Nigro G, Mazzocco M, Best AM, Adler SP. Placental enlargement in women with primary maternal cytomegalovirus infection is associated with fetal and neonatal disease. Clin Infect Dis. 2006;43:994-1000.

52. Grannum PA. Ultrasound examination of the placenta. Clin Obstet Gynaecol. 1983:10:459-73.

53. Doneda C, Parazzini C, Righini A, Rustico M, Tassis B, Fabbri E, et al Early cerebral lesions in cytomegalovirus infection: prenatal MR imaging. Radiology. 2010;255:613-21.

54. Cannie MM, Devlieger R, Leyder M, Claus F, Leus A, De Catte L, et al. Congenital cytomegalovirus infection: contribution and best timing of prenatal MR imaging. Eur Radiol. 2016;26:3760-9.

55. Averill LW, Kandula VV, Akyol Y, Epelman M. Fetal brain magnetic resonance imaging findings in congenital cytomegalovirus infection with postnatal imaging correlation. Semin Ultrasound CT MR. 2015;36:476-86.

56. Salomon LJ, Alfirevic Z Da Silva Costa F, Deter RL, Figueras F, Ghi T, et al. ISUOG Practice Guidelines: ultrasound assessment of fetal biometry and growth. Ultrasound Obstet Gynecol. 2019;53:715-23.

57. Enders M, Daiminger A, Exler S, Ertan K, Enders G, Bald R. Prenatal diagnosis of congenital cytomegalovirus infection in 115 cases: a 5 years' single center experience. Prenat Diagn. 2017;37:389-98.

58. Picone O, Simon I, Benachi A, Brunelle F, Sonigo P. Comparison between ultrasound and magnetic resonance imaging in assessment of fetal cytomegalovirus infection. Prenat Diagn. 2008;28:753-8.

59. Goegebuer T, Van Meensel B, Beuselinck K, Cossey V, Van Ranst M Hanssens $M$, et al. Clinical predictive value of real-time PCR quantification of human cytomegalovirus DNA in amniotic fluid samples. J Clin Microbiol. 2009;47:660-5.

60. Gouarin S, Gault E, Vabret A, Cointe D, Rozenberg F, Grangeot-Keros L, et al. Real-time PCR quantification of human cytomegalovirus DNA in amniotic fluid samples from mothers with primary infection. J Clin Microbiol. 2002;40:1767-72.

61. De la Calle M, Baquero-Artigao F, Rodríguez-Molino P, Cabanes M, Cabrera $\mathrm{M}$, Antolín $\mathrm{E}$, et al. Combined treatment with immunoglobulin and valaciclovir in pregnant women with cytomegalovirus infection and high risk of symptomatic fetal disease. J Matern Fetal Neonatal Med. 2020 Sep 15;15. doi: 10.1080/14767058.2020.1815188. Online ahead of print

62. Zavattoni M, Furione M, Arossa A, lasci A, Spinillo A, Lombardi G, et al. Diagnosis and counseling of fetal and neonatal HCMV infection. Early Hum Dev. 2014:90 (Suppl 1):S29-S31.

63. Rivera LB, Boppana SB, Fowler KB, Britt WJ, Stagno S, Pass RF. Predictors of hearing loss in children with symptomatic congenital cytomegalovirus infection. Pediatrics. 2002;110:762-7.
64. Schwab I, Nimmerjahn F. Intravenous immunoglobulin therapy: how does IgG modulate the immune system? Nat Rev Immunol. 2013;13:176-89.

65. Nigro G, Adler SP, La Torre R, Best AM, Congenital Cytomegalovirus Collaborating Group. Passive immunization during pregnancy for congenital cytomegalovirus infection. N Engl J Med. 2005;353:1350-62.

66. Revello MG, Lazzarotto T, Guerra B, Spinillo A, Ferrazzi E, Kustermann A, et al. A randomized trial of hyperimmune globulin to prevent congenital cytomegalovirus. N Engl J Med. 2014;370:1316-26.

67. Hughes BL, Clifton RG, Rouse DJ, Saade GR, Dinsmoor MJ, Reddy UM, et al. A trial of hyperimmune globulin to prevent congenital cytomegalovirus infection. N Engl J Med. 2021;385:436-44.

68. Hamprecht K, Kagan KO, Goelz R. Hyperimmune globulin to prevent congenital CMV infection. N Engl J Med. 2014;370:2543

69. Kagan KO, Enders M, Schampera MS, Baeumel E, Hoopmann M, Geipel A, et al. Prevention of maternal-fetal transmission of cytomegalovirus after primary maternal infection in the first trimester by biweekly hyperimmunoglobulin administration. Ultrasound Obstet Gynecol. 2019;53:383-9.

70. Nigro G, Adler SP, Congenital Cytomegalic Disease Collaborating Group. High-dose cytomegalovirus (CMV) hyperimmune globulin and maternal CMV DNAemia independently predict infant outcome in pregnant women with a primary CMV infection. Clin Infect Dis. 2020:71:1491-8.

71. Kagan KO, Enders M, Hoopmann M, Geipel A, Simonini C, Berg C, et al. Outcome of pregnancies with recent primary cytomegalovirus infection in first trimester treated with hyperimmunoglobulin: observational study. Ultrasound Obstet Gynecol. 2021;57:560-7.

72. Ahmed A. Antiviral treatment of cytomegalovirus infection. Infect Disord Drug Targets. 2011;11:475-503.

73. Kotton CN. Updates on antiviral drugs for cytomegalovirus prevention and treatment. Curr Opin Organ Transplant. 2019;24:469-75.

74. Jacquemard F, Yamamoto M, Costa JM, Romand S, Jaqz-Aigrain E, Dejean $A$, et al. Maternal administration of valaciclovir in symptomatic intrauterine cytomegalovirus infection. $\mathrm{Br} J$ Obstet Gynecol. 2007;114:1113-21.

75. Hamilton ST, Marschall M, Rawlinson WD. Investigational antiviral therapy models for the prevention and treatment of congenital cytomegalovirus infection during pregnancy. Antimicrob Agents Chemother. 2020;65:e01627-20.

76. Zammarchi L, Lazzarotto T, Di Tommaso M, Tomasoni L, Pasquini L, Galli $L$, et al. Valacyclovir for prevention and treatment of fetal CMV infection: inclusion in the Law 648/96 list and launch of the Italian multicentre observational prospective study "MEGAL-ITALI". Infez Med. 2021;29:299-303.

77. Ong SY, Truong HT, Diong CP, Linn YC, Ho AY, Goh YT, et al. Use of valacyclovir for the treatment of cytomegalovirus antigenemia after hematopoietic stem cell transplantation. BMC Hematol. 2015;15:8.

78. Shahar-Nissan K, Pardo J, Peled O, Krause I, Bilavsky E, Wiznitzer A, et al. Valaciclovir to prevent vertical transmission of cytomegalovirus after maternal primary infection during pregnancy: a randomised, double-blind, placebo-controlled trial. Lancet. 2020;396:779-85.

79. Blazquez-Gamero D, Galindo Izquierdo A, Del Rosal T, Baquero-Artigao F, Izquierdo Mendez N, Soriano-Ramos M, et al. Prevention and treatment of fetal cytomegalovirus infection with cytomegalovirus hyperimmune globulin: a multicenter study in Madrid. J Matern Fetal Neonatal Med. 2019:32:617-25.

80. FALTA 80

81. De la Calle M, Baquero F, Rodriguez R, Gonzalez M, Fernandez A, Omenaca $\mathrm{F}$, et al. Successful treatment of intrauterine cytomegalovirus infection with an intraventricular cyst in a dichorionic diamniotic twin gestation using cytomegalovirus immunoglobulin. J Matern Fetal Neonatal Med. 2018;31:2226-9.

82. Buxmann H, Stackelberg OM, Schlosser RL, Enders G, Gonser M, Meyer-Wittkopf $M$, et al. Use of cytomegalovirus hyperimmunoglobulin for prevention of congenital cytomegalovirus disease: a retrospective analysis. J Perinat Med. 2012;40:439-46.

83. Visentin S, Manara R, Milanese L, Da Roit A, Forner G, Salviato E, et al. Early primary cytomegalovirus infection in pregnancy: maternal hyperimmunoglobulin therapy improves outcomes among infants at 1 year of age. Clin Infect Dis. 2012:55:497-503.

84. Seidel V, Feiterna-Sperling C, Siedentopf JP, Hofmann J, Henrich W, Buhrer $\mathrm{C}$, et al. Intrauterine therapy of cytomegalovirus infection with valganciclovir: review of the literature. Med Microbiol Immunol. 2017;206:347-54.

85. Bergin S, Ferguson W, Corcoran S, Varughese A, Byrne D, Lawless M, et al. Symptomatic primary cytomegalovirus infection in a HIV-positive pregnant woman. Int J STD AIDS. 2014;25:1041-3.

86. Puliyanda DP, Silverman NS, Lehman D, Vo A, Bunnapradist S, Radha RK, et al. Successful use of oral ganciclovir for the treatment of intrauterine cytomegalovirus infection in a renal allograft recipient. Transpl Infect Dis. 2005;7:71-4.

87. Leruez-Ville M, Ville Y. Optimum treatment of congenital cytomegalovirus infection. Expert Rev Anti Infect Ther. 2016;14:479-88.

88. Marty FM, Ljungman P, Chemaly RF, Maertens J, Dadwal SS, Duarte RF, et al. Letermovir prophylaxis for cytomegalovirus in hematopoietic-cell transplantation. N Engl J Med. 2017;377:2433-44. 
89. Revello MG, Tibaldi C, Masuelli G, Frisina V, Sacchi A, Furione M, et al. Prevention of primary cytomegalovirus infection in pregnancy. EBioMedicine. 2015;2:1205-10.

90. Leruez-Ville M, Khalil A, Kagan KO, Donner C, Lazzarotto T, Ville Y. Antenatal screening for cytomegalovirus infection: to know the chance, the chance to know. Lancet Child Adolesc Health. 2019;3:675-7.

91. Hyde TB, Schmid DS, Cannon MJ. Cytomegalovirus seroconversion rates and risk factors: implications for congenital CMV. Rev Med Virol. 2010;20:311-26

92. Lanzieri TM, Gastanaduy PA, Gambhir M, Plotkin SA. Review of mathematical models of vaccination for preventing congenital cytomegalovirus infection. J Infect Dis. 2020;221 (Suppl 1):S86-S93.

93. Esposito S, Chiopris G, Messina G, D'Alvano T, Perrone S, Principi N. Prevention of congenital cytomegalovirus infection with vaccines: state of the art. Vaccines (Basel). 2021;9:523.

94. Gerna G, Fornara C, Furione M, Lilleri D. Congenital human cytomegalovirus infection: a narrative review of maternal immune response and diagnosis in view of the development of a vaccine and prevention of primary and non-primary infections in pregnancy. Microorganisms. 2021;9:1749.

95. Kilby MD, Ville $Y$, Acharya G. Screening for cytomegalovirus infection in pregnancy. Br Med J. 2019;367:16507.

96. Luck SE, Wieringa JW, Blazquez-Gamero D, Henneke P, Schuster K Butler K, et al. Congenital cytomegalovirus: a European expert consensus statement on diagnosis and management. Pediatr Infect Dis $\mathrm{J}$. 2017;36:1205-13.

97. Kylat RI, Kelly EN, Ford-Jones EL. Clinical findings and adverse outcome in neonates with symptomatic congenital cytomegalovirus (SCCMV) infection. Eur J Pediatr. 2006;165:773-8.

98. Belzile JP, Stark TJ, Yeo GW, Spector DH. Human cytomegalovirus infection of human embryonic stem cell-derived primitive neural stem cells is restricted at several steps but leads to the persistence of viral DNA J Virol. 2014;88:4021-39.

99. Wei D, Sardesai SR, Barton L. The C in TORCH: a cost-effective alternative to screening small-for-gestational-age infants. Neonatology. 2014;106:24-9.

100. Lorenzoni F, Lunardi S, Liumbruno A, Ferri G, Madrigali V, Fiorentini E, et al. Neonatal screening for congenital cytomegalovirus infection in preterm and small for gestational age infants. J Matern Fetal Neonatal Med. 2014;27:1589-93.

101. Chuang Chuang A, Ramos Hernández H, Zelada Bacigualupo U, López Castillo MT, Villavicencio Landeros L, Peret LM, et al. Congenital cytomegalovirus infection screening in high risk newborn. Rev Chil Infectol. 2021:38:45-53.

102. Norma conjunta de prevención de la transmisión vertical del VIH y la sífilis. Ministerio de Salud de Chile. Programa Nacional de Prevención y Control de la Infección por VIH/SIDA e ITS. División de Prevención y Control de Enfermedades. Subsecretaría de Salud Pública. Ministerio de Salud. Rev Chil Infectol. 2013;30:259-302.

103. Pena A, Ceron I, Budnik I, Barttlet D, Cataldo K, Fernández AM, et al. [Prevention of vertical transmission and side effects of antiretroviral therapy in children born to HIV-positive South Eastern area of Santiago, Chile: 15-years perspective]. Rev Chil Infectol. 2013;30:644-52.

104. Marín Gabriel MA, Fernández Ibieta M, González Tome MI, Saavedra Lozano J, Barajas Sánchez V, Rojo Conejo P, et al. Congenital cytomegalovirus infection in the infants of HIV-infected mothers. An Pediatr (Barc). 2005;62:38-42

105. Dorfman JR, Balla SR, Pathirana J, Groome MJ, Madhi SA, Moore PL. In utero human cytomegalovirus infection is associated with increased levels of putatively protective maternal antibodies in nonprimary infection: evidence for boosting but not protection. Clin Infect Dis. 2021;73:e981-e7.

106. Duryea EL, Sanchez PJ, Sheffield JS, Jackson GL, Wendel GD, McElwee BS, et al. Maternal human immunodeficiency virus infection and congenital transmission of cytomegalovirus. Pediatr Infect Dis $\mathrm{J}$. 2010;29:915-8

107. Manicklal S, van Niekerk AM, Kroon SM, Hutto C, Novak Z, Pati SK, et al. Birth prevalence of congenital cytomegalovirus among infants of HIV-infected women on prenatal antiretroviral prophylaxis in South Africa. Clin Infect Dis. 2014;58:1467-72.

108. Purswani MU, Russell JS, Dietrich M, Malee K, Spector SA, Williams PL, et al. Birth prevalence of congenital cytomegalovirus infection in HIV-exposed uninfected children in the era of combination antiretroviral therapy. J Pediatr. 2020;216:82-7e2.

109. Frederick T, Homans J, Spencer L, Kramer F, Stek A, Operskalski E, et al. The effect of prenatal highly active antiretroviral therapy on the transmission of congenital and perinatal/early postnatal cytomegalovirus among HIV-infected and HIV-exposed infants. Clin Infect Dis. 2012:55:877-84.

110. American Academy of Pediatrics Joint Committee on Infant Hearing. Year 2007 position statement: Principles and guidelines for early hearing detection and intervention programs. Pediatrics. 2007;120:898-921.

111. Hicks T, Fowler K, Richardson M, Dahle A, Adams L, Pass R. Congenital cytomegalovirus infection and neonatal auditory screening. J Pediatr. 1993;123:779-82.
112. Fowler KB, McCollister FP, Sabo DL, Shoup AG, Owen KE, Woodruff JL et al. A targeted approach for congenital cytomegalovirus screening within newborn hearing screening. Pediatrics. 2017;139:e20162128.

113. Kawada J, Torii Y, Kawano Y, Suzuki M, Kamiya Y, Kotani T, et al. Viral load in children with congenital cytomegalovirus infection identified on newborn hearing screening. J Clin Virol. 2015;65:41-5.

114. Diener ML, Zick CD, McVicar SB, Boettger J, Park AH. Outcomes from a hearing-targeted cytomegalovirus screening program. Pediatrics. 2017; 139:e20160789.

115. Ronchi A, Zeray F, Lee LE, Owen KE, Shoup AG, Garcia F, et al. Evaluation of clinically asymptomatic high risk infants with congenital cytomegalovirus infection. J Perinatol. 2020;40:89-96.

116. Blazquez-Gamero D, Soriano-Ramos M, Vicente M, Pallas-Alonso CR, Perez-Rivilla A, Garcia-Alvarez M, et al. Prevalence and clinical manifestations of congenital cytomegalovirus infection in a screening program in Madrid (PICCSA Study). Pediatr Infect Dis J. 2020;39:1050-6.

117. Blazquez-Gamero D, Soriano-Ramos M, Martinez de Aragon A, Baquero-Artigao F, Frick MA, Noguera-Julian A, et al. Role of magnetic resonance imaging and cranial ultrasonography in congenital cytomegalovirus infection. Pediatr Infect Dis J. 2019;38:1131-7.

118. Boppana SB, Pass RF, Britt WJ, Stagno S, Alford CA. Symptomatic congenital cytomegalovirus infection: neonatal morbidity and mortality. Pediatr Infect Dis J. 1992;11:93-9.

119. Korndewal MJ, Oudesluys-Murphy AM, Kroes ACM, van der Sande MAB, de Melker HE, Vossen A. Long-term impairment attributable to congenital cytomegalovirus infection: a retrospective cohort study. Dev Med Child Neurol. 2017;59:1261-8.

120. Lazzarotto T, Guerra B, Lanari M, Gabrielli L, Landini MP. New advances in the diagnosis of congenital cytomegalovirus infection. J Clin Virol. 2008;41:192-7.

121. Schlesinger Y, Halle D, Eidelman AI, Reich D, Dayan D, Rudensky B, et al. Urine polymerase chain reaction as a screening tool for the detection of congenital cytomegalovirus infection. Arch Dis Child Fetal Neonatal Ed. 2003;88:F371-4.

122. Stagno S, Pass RF, Cloud G, Britt WJ, Henderson RE, Walton PD, et al. Primary cytomegalovirus infection in pregnancy. Incidence, transmission to fetus, and clinical outcome. JAMA. 1986;256:1904-8.

123. Ross SA, Ahmed A, Palmer AL, Michaels MG, Sanchez PJ, Stewart A, et al. Urine collection method for the diagnosis of congenital cytomegalovirus infection. Pediatr Infect Dis J. 2015;34:903-5.

124. Pinninti SG, Ross SA, Shimamura M, Novak Z, Palmer AL, Ahmed A, et al. Comparison of saliva PCR assay versus rapid culture for detection of congenital cytomegalovirus infection. Pediatr Infect Dis J. 2015:34:536-7.

125. De Monte A, Cannavo I, Caramella A, Ollier L, Giordanengo V. Analytical performances of real-time PCR by Abbott RealTime CMV with m2000 for the detection of cytomegalovirus in urine. Ann Biol Clin (Paris). 2016;74:244-50.

126. Boppana SB, Ross SA, Shimamura $M$, Palmer AL, Ahmed A Michaels MG, et al. Saliva polymerase-chain-reaction assay for cytomegalovirus screening in newborns. N Engl J Med. 2011;364:2111-8.

127. Chiopris G, Veronese P, Cusenza F, Procaccianti M, Perrone S Dacco V, et al. Congenital cytomegalovirus infection: update on diagnosis and treatment. Microorganisms. 2020;8:1516.

128. Exler S, Daiminger A, Grothe M, Schalasta G, Enders G, Enders M. Primary cytomegalovirus (CMV) infection in pregnancy: diagnostic value of CMV PCR in saliva compared to urine at birth. J Clin Virol. 2019;117:33-6.

129. Revello MG, Zavattoni M, Baldanti F, Sarasini A, Paolucci S, Gerna G. Diagnostic and prognostic value of human cytomegalovirus load and IgM antibody in blood of congenitally infected newborns. J Clin Virol. 1999;14:57-66.

130. Ohyama S, Fujioka K, Fukushima S, Abe S, Ashina M, Ikuta T, et al. Diagnostic value of cytomegalovirus IgM antibodies at birth in pcr-confirmed congenital cytomegalovirus infection. Int J Mol Sci. 2019;20:3239.

131. Lanari M, Lazzarotto T, Venturi V, Papa I, Gabrielli L, Guerra B, et al. Neonatal cytomegalovirus blood load and risk of sequelae in symptomatic and asymptomatic congenitally infected newborns. Pediatrics. 2006; $117:$ :e76-83.

132. Boppana SB, Ross SA, Novak Z, Shimamura M, Tolan RW Jr., Palmer AL, et al. Dried blood spot real-time polymerase chain reaction assays to screen newborns for congenital cytomegalovirus infection. JAMA. 2010;303:1375-82.

133. Dollard SC, Dreon M, Hernandez-Alvarado N, Amin MM, Wong P, Lanzieri TM, et al. Sensitivity of dried blood spot testing for detection of congenital cytomegalovirus infection. JAMA Pediatr. 2021;175:e205441.

134. Kimberlin DW, Acosta EP, Sanchez PJ, Sood S, Agrawal V, Homans J, et al. Pharmacokinetic and pharmacodynamic assessment of oral valganciclovir in the treatment of symptomatic congenital cytomegalovirus disease. J Infect Dis. 2008;197:836-45.

135. Luck SE, Emery VC, Atkinson C, Sharland M, Griffiths PD. Compartmentalized dynamics of cytomegalovirus replication in treated congenital infection. J Clin Virol. 2016;82:152-8.

136. Alarcón R J, Alarcón VY, Hering AE, Buccioni VR. Curvas antropométricas de recién nacidos chilenos. Rev Chil Pediatr. 2008;79:364-72.

137. Pittaluga PE, Díaz AV, Mena NP, Corvalán VS. Curva de crecimiento intrauterino para prematuros entre 23 a 36 semanas de edad gestacional. Rev Chil Pediatr. 2002;73:135-41. 
Rev Chil Obstet Ginecol. 2021;86(6)

138. Marsico C, Aban I, Kuo H, James SH, Sanchez PJ, Ahmed A, et al. Blood viral load in symptomatic congenital cytomegalovirus infection. J Infect Dis. 2019;219:1398-406

139. Smiljkovic M, Le Meur JB, Malette B, Boucoiran I, Minsart AF, Lamarre V, et al. Blood viral load in the diagnostic workup of congenital cytomegalovirus infection. J Clin Virol. 2020;122:104231.

140. Troendle Atkins J, Demmler GJ, Williamson WD, McDonald JM, Istas AS, Buffone GJ. Polymerase chain reaction to detect cytomegalovirus DNA in the cerebrospinal fluid of neonates with congenital infection. J Infect Dis. 1994;169:1334-7.

141. Ouellette C, Ronchi A, Mejias A, Chavez-Bueno S, Salamon D, Pugni L, et al. 998: Detection of cytomegalovirus (CMV) in cerebrospinal fluid of infants with congenital cmv infection: is it worth doing the lumbar puncture? Open Forum Infect Dis. 2014;1 (Suppl 1):S292.

142. Goycochea-Valdivia WA, Baquero-Artigao F, Del Rosal T, Frick MA Rojo P, Echeverria MJ, et al. Cytomegalovirus DNA detection by polymerase chain reaction in cerebrospinal fluid of infants with congenital infection: associations with clinical evaluation at birth and implications for follow-up. Clin Infect Dis. 2017:64:1335-42.

143. Czech-Kowalska J, Jedlinska-Pijanowska D, Kasztelewicz B, Klodzinska M, Pietrzyk A, Sarkaria E, et al. The limitations of cytomegalovirus DNA detection in cerebrospinal fluid of newborn infants with congenital CMV infection: a tertiary care neonatal center experience. Pediatr Infect Dis J. 2021;40:838-45.

144. Gaur P, French-Constant S, Kachramanoglou C, Lyall H, Jan W. Is it no time for international guidelines to combat congenital cytomegalovirus infection? A review of central nervous system manifestations. Clin Radiol. 2020;75:644.e7-16

145. Cantey JB, Sisman J. The etiology of lenticulostriate vasculopathy and the role of congenital infections. Early Hum Dev. 2015;91:427-30.

146. Smiljkovic M, Renaud C, Tapiero B, Lamarre V, Kakkar F. Head ultrasound, CT or MRI? The choice of neuroimaging in the assessment of infants with congenital cytomegalovirus infection. BMC Pediatr. 2019;19:180.

147. Noyola DE, Demmler GJ, Nelson CT, Griesser C, Williamson WD, Atkins JT, et al. Early predictors of neurodevelopmental outcome in symptomatic congenital cytomegalovirus infection. J Pediatr. 2001;138:325-31.

148. Capretti MG, Lanari M, Tani G, Ancora G, Sciutti R, Marsico C, et al. Role of cerebral ultrasound and magnetic resonance imaging in newborns with congenital cytomegalovirus infection. Brain Dev. 2014;36:203-11.

149. Antonov NK, Ruzal-Shapiro CB, Morel KD, Millar WS, Kashyap S, Lauren CT, et al. Feed and Wrap MRI Technique in Infants. Clin Pediatr (Phila). 2017:56:1095-103.

150. Sánchez DN, Castoldi LMF, Stecher GX. RM de encéfalo sin anestesia en pacientes recién nacidos: experiencia inicial en Clínica Alemana de Santiago. Rev Chil Radiol. 2014;20:143-8.

151. Dhondt C, Maes L, Rombaut L, Martens S, Vanaudenaerde S, Van Hoecke $\mathrm{H}$, et al. Vestibular function in children with a congenital cytomegalovirus infection: 3 years of follow-up. Ear Hear. 2020;42:76-86

152. Cohen VJ, Cohen VM. Citomegalovirus congénito: rol etiológico en la sordera del niño. Rev Med Clin Las Condes. 2014;25:425-31

153. Year 2019 Position Statement: Principles and Guidelines for Early Hearing Detection and Intervention Programs. Journal Early Hearing Detection Intervention. 2019:4:1-44

154. Natale F, De Curtis M, Bizzarri B, Orlando MP, Ralli M, Liuzzi G, et al. Isolated auditory neuropathy at birth in congenital cytomegalovirus infection. Italian J Pediatr. 2020;46:3.

155. Awad R, Oropeza J, Uhler KM. Meeting the Joint Committee on Infant Hearing Standards in a large metropolitan children's hospital: barriers and next steps. Am J Audiol. 2019;28:251-9.

156. Superintendencia de Salud. Chile. Tratamiento de hipoacusia moderada severa y profunda en personas menores de 4 años. Disponible en: https://www.supersalud.gob.cl/difusion/665/w3-article-18921.html

157. Superintendencia de Salud. Chile. Hipoacusia sensorioneural en el prematuro. Disponible en: https://www.supersalud.gob.cl/difusion/665/w3-article-18875.html

158. Coats DK, Demmler GJ, Paysse EA, Du LT, Libby C. Ophthalmologic findings in children with congenital cytomegalovirus infection. J AAPOS. 2000;4:110-6

159. Capretti MG, Marsico C, Guidelli Guidi S, Ciardella A, Simonazzi G, Galletti S, et al. Neonatal and long-term ophthalmological findings in infants with symptomatic and asymptomatic congenital cytomegalovirus infection. J Clin Virol. 2017;97:59-63.

160. Ghekiere S, Allegaert K, Cossey V, Van Ranst M, Cassiman C, Casteels I. Ophthalmological findings in congenital cytomegalovirus infection: when to screen, when to treat? J Pediatr Ophthalmol Strabismus. 2012;49:274-82.

161. Jin HD, Demmler-Harrison GJ, Coats DK, Paysse EA, Bhatt A, Edmond JC, et al. Long-term visual and ocular sequelae in patients with congenital cytomegalovirus infection. Pediatr Infect Dis J. 2017;36:877-82.

162. Lawrence MM, Feind CR. Vestibular responses to rotation in the newborn infant. Pediatrics. 1953;12:300-6.

163. Kimberlin DW, Lin CY, Sanchez PJ, Demmler GJ, Dankner W, Shelton M, et al. Effect of ganciclovir therapy on hearing in symptomatic congenital cytomegalovirus disease involving the central nervous system: a randomized, controlled trial. J Pediatr. 2003;143:16-25.
164. Kimberlin DW, Jester PM, Sanchez PJ, Ahmed A, Arav-Boger R, Michaels $M G$, et al. Valganciclovir for symptomatic congenital cytomegalovirus disease. N Engl J Med. 2015;372:933-43.

165. U.S. Department of Health and Human Services, National Institutes of Health, National Institute of Allergy and Infectious Diseases, Division of AIDS. Division of AIDS (DAIDS) table for grading the severity of adult and pediatric adverse events, corrected version 2.1. [July 2017]. Disponible en: https://rsc.niaid.nih.gov/sites/default/files/daidsgradingcorrectedv21.pdf

166. Lanzieri TM, Chung W, Flores M, Blum P, Caviness AC, Bialek SR, et al. Hearing loss in children with asymptomatic congenital cytomegalovirus infection. Pediatrics. 2017;139:e20162610.

167. Torrecillas V, Allen CM, Greene T, Park A, Chung W, Lanzieri TM, et al. Should you follow the better-hearing ear for congenital cytomegalovirus infection and isolated sensorineural hearing loss? Otolaryngol Head Neck Surg. 2020;162:114-20

168. Bernard S, Wiener-Vacher S, Van Den Abbeele T, Teissier N. Vestibular disorders in children with congenital cytomegalovirus infection. Pediatrics. 2015;136:e887-95

169. Khalil A, Heath $P$, Jones $C$, Soe A, Ville YG; on behalf of the Royal College of Obstetricians and Gynaecologists. Congenital cytomegalovirus infection: update on treatment. Scientific impact paper No. 56. Br J Obstet Gynecol. 2018;125:e1-11.

170. Sakamoto A, Moriuchi H, Matsuzaki J, Motoyama K, Moriuchi M. Retrospective diagnosis of congenital cytomegalovirus infection in children with autism spectrum disorder but no other major neurologic deficit. Brain Dev. 2015;37:200-5

171. Topham JD, Miller JA, Wright GW, Turcich M, Vinson SS, lovino I, et al. Inattention and hyperactivity in children with symptomatic and asymptomatic congenital cytomegalovirus. J Dev Behav Pediatr. 2019;40:743-50.

172. Pass RF, Fowler KB, Boppana SB, Britt WJ, Stagno S. Congenital cytomegalovirus infection following first trimester maternal infection: symptoms at birth and outcome. J Clin Virol. 2006;35:216-20.

173. MacDonald $\mathrm{H}$, Tobin $\mathrm{JH}$. Congenital cytomegalovirus infection: a collaborative study on epidemiological, clinical and laboratory findings. Dev Med Child Neurol. 1978;20:471-82.

174. Stagno S, Pass RF, Thomas JP, Navia JM, Dworsky ME. Defects of tooth structure in congenital cytomegalovirus infection. Pediatrics. 1982:69:646-8.

175. Remington JS, Klein JO. Infectious diseases of the fetus and newborn infant. $7^{\text {th }}$ ed. Philadelphia, PA: Elsevier - W.B. Saunders; 2011.

176. Gobierno de Chile, Ministerio de Salud. Normas para el óptimo desarrollo de programas de búsqueda masiva de fenilquetonuria (PKU) e hipotiroidismo congénito $(\mathrm{HC})$ y otros errores innatos del metabolismo (EIM). 2007. Disponible em: https://diprece.minsal.cl/wrdprss minsal/wp-content/uploads/2015/10/2007_Normas-para-el-Optimo-de-búsqueda-masiva-de-Fenilcetonuria.pdf

177. Ronchi A, Shimamura M, Malhotra PS, Sanchez PJ. Encouraging postnatal cytomegalovirus (CMV) screening: the time is NOW for universal screening! Expert Rev Anti Infect Ther. 2017;15:417-9.

178. Hilditch C, Liersch B, Spurrier N, Callander EJ, Cooper C, Keir AK. Does screening for congenital cytomegalovirus at birth improve longer term hearing outcomes? Arch Dis Child. 2018;103:988-92.

179. Cannon MJ, Griffiths PD, Aston V, Rawlinson WD. Universal newborn screening for congenital CMV infection: what is the evidence of potential benefit? Rev Med Virol. 2014;24:291-307.

180. Kaye Cl; Committee on Genetics, Accurso F, La Franchi S, Lane PA, Hope N, et al. Newborn screening fact sheets. Pediatrics. 2006;118:e934-63.

181. Williams EJ, Kadambari S, Berrington JE, Luck S, Atkinson C, Walter S, et al. Feasibility and acceptability of targeted screening for congenital CMV-related hearing loss. Arch Dis Child Fetal Neonatal Ed. 2014;99:F230-6.

182. Vancor E, Shapiro ED, Loyal J. Results of a targeted screening program for congenital cytomegalovirus infection in infants who fail newborn hearing screening. J Pediatric Infect Dis Soc. 2019;8:55-9.

183. Rawlinson WD, Palasanthiran $P$, Hall B, Al Yazidi L, Cannon MJ, Cottier $\mathrm{C}$, et al. Neonates with congenital cytomegalovirus and hearing loss identified via the universal newborn hearing screening program. $\mathrm{J}$ Clin Virol. 2018;102:110-5.

184. Alarcón Allen A, Baquero-Artigao F, Grupo de estudio de la infeccion por citomegalovirus de la Sociedad Espanola de Infectologia Pediátrica. Review and guidelines on the prevention, diagnosis and treatment of post-natal cytomegalovirus infection. An Pediatr (Barc). 2011:74:52e1-13.

185. Escosa-García L, Baquero-Artigao F, Noguera Julián A, Blazquez Gamero D; Comité Científico del Registro Estatal de Infección Congénita por Citomegalovirus. Cytomegalovirus screening in less than $1500 \mathrm{~g}$ premature newborns. National Congenital Cytomegalovirus Disease Registry Scientific committee. An Pediatr (Barc). 2015;83:70-1.

186. Lazzarotto T, Blazquez-Gamero D, Delforge ML, Foulon I, Luck S, Modrow S, et al. Congenital cytomegalovirus infection: a narrative review of the issues in screening and management from a panel of European experts. Front Pediatr. 2020;8:13

187. Lunardi S, Lorenzoni F, Ghirri P. Universal screening for congenital CMV infection. Update on Critical Issues on Infant and Neonatal Care. 2019. Disponible en: https://www.intechopen.com/chapters/69364 